\title{
ON Liberty
}

\section{John Stuart Mill \\ 1859}

Batoche Books

Kitchener

2001 
Batoche Books Limited 52 Eby Street South

Kitchener, Ontario

N2G 3L1

Canada

email: batoche@gto.net 


\section{Contents}

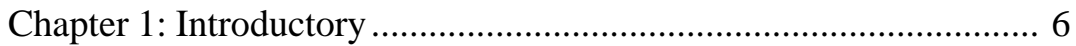

Chapter 2: Of the Liberty of Thought and Discussion.................... 18

Chapter 3: Of Individuality, as one of the Elements of Well-being. . 52

Chapter 4: Of the Limits to the Authority of Society over the Indi-

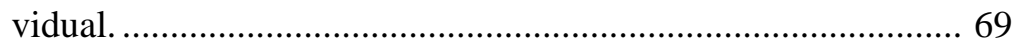

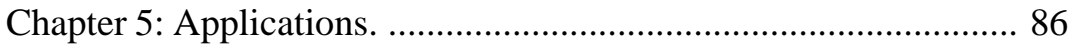

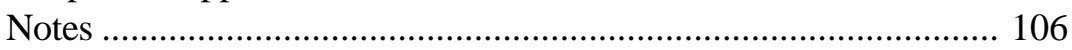





\section{Dedication}

The grand, leading principle, towards which every argument unfolded in these pages directly converges, is the absolute and essential importance of human development in its richest diversity.

Wilhelm von Humboldt: Sphere and Duties of Government.

To the beloved and deplored memory of her who was the inspirer, and in part the author, of all that is best in my writings- the friend and wife whose exalted sense of truth and right was my strongest incitement, and whose approbation was my chief reward-I dedicate this volume. Like all that I have written for many years, it belongs as much to her as to me; but the work as it stands has had, in a very insufficient degree, the inestimable advantage of her revision; some of the most important portions having been reserved for a more careful re-examination, which they are now never destined to receive. Were I but capable of interpreting to the world one half the great thoughts and noble feelings which are buried in her grave, I should be the medium of a greater benefit to it, than is ever likely to arise from anything that I can write, unprompted and unassisted by her all but unrivalled wisdom. 


\section{Chapter 1 Introductory}

The subject of this Essay is not the so-called Liberty of the Will, so unfortunately opposed to the misnamed doctrine of Philosophical Necessity; but Civil, or Social Liberty: the nature and limits of the power which can be legitimately exercised by society over the individual. A question seldom stated, and hardly ever discussed, in general terms, but which profoundly influences the practical controversies of the age by its latent presence, and is likely soon to make itself recognised as the vital question of the future. It is so far from being new, that, in a certain sense, it has divided mankind, almost from the remotest ages; but in the stage of progress into which the more civilised portions of the species have now entered, it presents itself under new conditions, and requires a different and more fundamental treatment.

The struggle between Liberty and Authority is the most conspicuous feature in the portions of history with which we are earliest familiar, particularly in that of Greece, Rome, and England. But in old times this contest was between subjects, or some classes of subjects, and the Government. By liberty, was meant protection against the tyranny of the political rulers. The rulers were conceived (except in some of the popular governments of Greece) as in a necessarily antagonistic position to the people whom they ruled. They consisted of a governing One, or a governing tribe or caste, who derived their authority from inheritance or conquest, who, at all events, did not hold it at the pleasure of the governed, and whose supremacy men did not venture, perhaps did not desire, to contest, whatever precautions might be taken against its oppressive exercise. Their power was regarded as necessary, but also as highly dangerous; as a weapon which they would attempt to use against their subjects, no less than against external enemies. To prevent the weaker members of the community from being preyed upon by innumerable vultures, it was needful that there should be an animal of prey stronger than the rest, commissioned to keep them down. But as the king of the vultures would be no less bent upon preying on the flock than any of the minor harpies, it was indispensable to be in a perpetual attitude of defence against his beak and claws. The aim, therefore, of patriots was to set limits to the power which the ruler should be suffered to exercise over the community; and this limitation was what they meant by liberty. It was attempted in two ways. First, by obtaining a recognition of certain immunities, called political liberties or rights, which it was to be 
regarded as a breach of duty in the ruler to infringe, and which if he did infringe, specific resistance, or general rebellion, was held to be justifiable. A second, and generally a later expedient, was the establishment of constitutional checks, by which the consent of the community, or of a body of some sort, supposed to represent its interests, was made a necessary condition to some of the more important acts of the governing power. To the first of these modes of limitation, the ruling power, in most European countries, was compelled, more or less, to submit. It was not so with the second; and, to attain this, or when already in some degree possessed, to attain it more completely, became everywhere the principal object of the lovers of liberty. And so long as mankind were content to combat one enemy by another, and to be ruled by a master, on condition of being guaranteed more or less efficaciously against his tyranny, they did not carry their aspirations beyond this point.

A time, however, came, in the progress of human affairs, when men ceased to think it a necessity of nature that their governors should be an independent power, opposed in interest to themselves. It appeared to them much better that the various magistrates of the State should be their tenants or delegates, revocable at their pleasure. In that way alone, it seemed, could they have complete security that the powers of government would never be abused to their disadvantage. By degrees this new demand for elective and temporary rulers became the prominent object of the exertions of the popular party, wherever any such party existed; and superseded, to a considerable extent, the previous efforts to limit the power of rulers. As the struggle proceeded for making the ruling power emanate from the periodical choice of the ruled, some persons began to think that too much importance had been attached to the limitation of the power itself. That (it might seem) was a resource against rulers whose interests were habitually opposed to those of the people. What was now wanted was, that the rulers should be identified with the people; that their interest and will should be the interest and will of the nation. The nation did not need to be protected against its own will. There was no fear of its tyrannising over itself. Let the rulers be effectually responsible to it, promptly removable by it, and it could afford to trust them with power of which it could itself dictate the use to be made. Their power was but the nation's own power, concentrated, and in a form convenient for exercise. This mode of thought, or rather perhaps of feeling, was common among the last generation of European liberalism, in the Continental section of which it still apparently predominates. 
Those who admit any limit to what a government may do, except in the case of such governments as they think ought not to exist, stand out as brilliant exceptions among the political thinkers of the Continent. A similar tone of sentiment might by this time have been prevalent in our own country, if the circumstances which for a time encouraged it, had continued unaltered.

But, in political and philosophical theories, as well as in persons, success discloses faults and infirmities which failure might have concealed from observation. The notion, that the people have no need to limit their power over themselves, might seem axiomatic, when popular government was a thing only dreamed about, or read of as having existed at some distant period of the past. Neither was that notion necessarily disturbed by such temporary aberrations as those of the French Revolution, the worst of which were the work of a usurping few, and which, in any case, belonged, not to the permanent working of popular institutions, but to a sudden and convulsive outbreak against monarchical and aristocratic despotism. In time, however, a democratic republic came to occupy a large portion of the earth's surface, and made itself felt as one of the most powerful members of the community of nations; and elective and responsible government became subject to the observations and criticisms which wait upon a great existing fact. It was now perceived that such phrases as "self-government," and "the power of the people over themselves," do not express the true state of the case. The "people" who exercise the power are not always the same people with those over whom it is exercised; and the "self-government" spoken of is not the government of each by himself, but of each by all the rest. The will of the people, moreover, practically means the will of the most numerous or the most active part of the people; the majority, or those who succeed in making themselves accepted as the majority; the people, consequently may desire to oppress a part of their number; and precautions are as much needed against this as against any other abuse of power. The limitation, therefore, of the power of government over individuals loses none of its importance when the holders of power are regularly accountable to the community, that is, to the strongest party therein. This view of things, recommending itself equally to the intelligence of thinkers and to the inclination of those important classes in European society to whose real or supposed interests democracy is adverse, has had no difficulty in establishing itself; and in political speculations "the tyranny of the majority" is now generally included among the evils against 
which society requires to be on its guard.

Like other tyrannies, the tyranny of the majority was at first, and is still vulgarly, held in dread, chiefly as operating through the acts of the public authorities. But reflecting persons perceived that when society is itself the tyrant-society collectively over the separate individuals who compose it-its means of tyrannising are not restricted to the acts which it may do by the hands of its political functionaries. Society can and does execute its own mandates: and if it issues wrong mandates instead of right, or any mandates at all in things with which it ought not to meddle, it practises a social tyranny more formidable than many kinds of political oppression, since, though not usually upheld by such extreme penalties, it leaves fewer means of escape, penetrating much more deeply into the details of life, and enslaving the soul itself. Protection, therefore, against the tyranny of the magistrate is not enough: there needs protection also against the tyranny of the prevailing opinion and feeling; against the tendency of society to impose, by other means than civil penalties, its own ideas and practices as rules of conduct on those who dissent from them; to fetter the development, and, if possible, prevent the formation, of any individuality not in harmony with its ways, and compels all characters to fashion themselves upon the model of its own. There is a limit to the legitimate interference of collective opinion with individual independence: and to find that limit, and maintain it against encroachment, is as indispensable to a good condition of human affairs, as protection against political despotism.

But though this proposition is not likely to be contested in general terms, the practical question, where to place the limit—how to make the fitting adjustment between individual independence and social controlis a subject on which nearly everything remains to be done. All that makes existence valuable to any one, depends on the enforcement of restraints upon the actions of other people. Some rules of conduct, therefore, must be imposed, by law in the first place, and by opinion on many things which are not fit subjects for the operation of law. What these rules should be is the principal question in human affairs; but if we except a few of the most obvious cases, it is one of those which least progress has been made in resolving. No two ages, and scarcely any two countries, have decided it alike; and the decision of one age or country is a wonder to another. Yet the people of any given age and country no more suspect any difficulty in it, than if it were a subject on which mankind had always been agreed. The rules which obtain among them- 


\section{0/John Stuart Mill}

selves appear to them self-evident and self-justifying.

This all but universal illusion is one of the examples of the magical influence of custom, which is not only, as the proverb says, a second nature, but is continually mistaken for the first. The effect of custom, in preventing any misgiving respecting the rules of conduct which mankind impose on one another, is all the more complete because the subject is one on which it is not generally considered necessary that reasons should be given, either by one person to others or by each to himself. People are accustomed to believe, and have been encouraged in the belief by some who aspire to the character of philosophers, that their feelings, on subjects of this nature, are better than reasons, and render reasons unnecessary. The practical principle which guides them to their opinions on the regulation of human conduct, is the feeling in each person's mind that everybody should be required to act as he, and those with whom he sympathises, would like them to act. No one, indeed, acknowledges to himself that his standard of judgment is his own liking; but an opinion on a point of conduct, not supported by reasons, can only count as one person's preference; and if the reasons, when given, are a mere appeal to a similar preference felt by other people, it is still only many people's liking instead of one. To an ordinary man, however, his own preference, thus supported, is not only a perfectly satisfactory reason, but the only one he generally has for any of his notions of morality, taste, or propriety, which are not expressly written in his religious creed; and his chief guide in the interpretation even of that. Men's opinions, accordingly, on what is laudable or blamable, are affected by all the multifarious causes which influence their wishes in regard to the conduct of others, and which are as numerous as those which determine their wishes on any other subject. Sometimes their reason-at other times their prejudices or superstitions: often their social affections, not seldom their antisocial ones, their envy or jealousy, their arrogance or contemptuousness: but most commonly their desires or fears for themselves - their legitimate or illegitimate self-interest.

Wherever there is an ascendant class, a large portion of the morality of the country emanates from its class interests, and its feelings of class superiority. The morality between Spartans and Helots, between planters and negroes, between princes and subjects, between nobles and roturiers, between men and women, has been for the most part the creation of these class interests and feelings: and the sentiments thus generated react in turn upon the moral feelings of the members of the ascen- 
dant class, in their relations among themselves. Where, on the other hand, a class, formerly ascendant, has lost its ascendancy, or where its ascendancy is unpopular, the prevailing moral sentiments frequently bear the impress of an impatient dislike of superiority. Another grand determining principle of the rules of conduct, both in act and forbearance, which have been enforced by law or opinion, has been the servility of mankind towards the supposed preferences or aversions of their temporal masters or of their gods. This servility, though essentially selfish, is not hypocrisy; it gives rise to perfectly genuine sentiments of abhorrence; it made men burn magicians and heretics. Among so many baser influences, the general and obvious interests of society have of course had a share, and a large one, in the direction of the moral sentiments: less, however, as a matter of reason, and on their own account, than as a consequence of the sympathies and antipathies which grew out of them: and sympathies and antipathies which had little or nothing to do with the interests of society, have made themselves felt in the establishment of moralities with quite as great force.

The likings and dislikings of society, or of some powerful portion of it, are thus the main thing which has practically determined the rules laid down for general observance, under the penalties of law or opinion. And in general, those who have been in advance of society in thought and feeling, have left this condition of things unassailed in principle, however they may have come into conflict with it in some of its details. They have occupied themselves rather in inquiring what things society ought to like or dislike, than in questioning whether its likings or dislikings should be a law to individuals. They preferred endeavouring to alter the feelings of mankind on the particular points on which they were themselves heretical, rather than make common cause in defence of freedom, with heretics generally. The only case in which the higher ground has been taken on principle and maintained with consistency, by any but an individual here and there, is that of religious belief: a case instructive in many ways, and not least so as forming a most striking instance of the fallibility of what is called the moral sense: for the odium theologicum, in a sincere bigot, is one of the most unequivocal cases of moral feeling. Those who first broke the yoke of what called itself the Universal Church, were in general as little willing to permit difference of religious opinion as that church itself. But when the heat of the conflict was over, without giving a complete victory to any party, and each church or sect was reduced to limit its hopes to retaining possession of the ground it al- 


\section{2/John Stuart Mill}

ready occupied; minorities, seeing that they had no chance of becoming majorities, were under the necessity of pleading to those whom they could not convert, for permission to differ. It is accordingly on this battle field, almost solely, that the rights of the individual against society have been asserted on broad grounds of principle, and the claim of society to exercise authority over dissentients openly controverted. The great writers to whom the world owes what religious liberty it possesses, have mostly asserted freedom of conscience as an indefeasible right, and denied absolutely that a human being is accountable to others for his religious belief. Yet so natural to mankind is intolerance in whatever they really care about, that religious freedom has hardly anywhere been practically realised, except where religious indifference, which dislikes to have its peace disturbed by theological quarrels, has added its weight to the scale. In the minds of almost all religious persons, even in the most tolerant countries, the duty of toleration is admitted with tacit reserves. One person will bear with dissent in matters of church government, but not of dogma; another can tolerate everybody, short of a Papist or a Unitarian; another every one who believes in revealed religion; a few extend their charity a little further, but stop at the belief in a God and in a future state. Wherever the sentiment of the majority is still genuine and intense, it is found to have abated little of its claim to be obeyed.

In England, from the peculiar circumstances of our political history, though the yoke of opinion is perhaps heavier, that of law is lighter, than in most other countries of Europe; and there is considerable jealousy of direct interference, by the legislative or the executive power, with private conduct; not so much from any just regard for the independence of the individual, as from the still subsisting habit of looking on the government as representing an opposite interest to the public. The majority have not yet learnt to feel the power of the government their power, or its opinions their opinions. When they do so, individual liberty will probably be as much exposed to invasion from the government, as it already is from public opinion. But, as yet, there is a considerable amount of feeling ready to be called forth against any attempt of the law to control individuals in things in which they have not hitherto been accustomed to be controlled by it; and this with very little discrimination as to whether the matter is, or is not, within the legitimate sphere of legal control; insomuch that the feeling, highly salutary on the whole, is perhaps quite as often misplaced as well grounded in the particular instances of its application. There is, in fact, no recognised principle by 
which the propriety or impropriety of government interference is customarily tested. People decide according to their personal preferences. Some, whenever they see any good to be done, or evil to be remedied, would willingly instigate the government to undertake the business; while others prefer to bear almost any amount of social evil, rather than add one to the departments of human interests amenable to governmental control. And men range themselves on one or the other side in any particular case, according to this general direction of their sentiments; or according to the degree of interest which they feel in the particular thing which it is proposed that the government should do, or according to the belief they entertain that the government would, or would not, do it in the manner they prefer; but very rarely on account of any opinion to which they consistently adhere, as to what things are fit to be done by a government. And it seems to me that in consequence of this absence of rule or principle, one side is at present as of wrong as the other; the interference of government is, with about equal frequency, improperly invoked and improperly condemned.

The object of this Essay is to assert one very simple principle, as entitled to govern absolutely the dealings of society with the individual in the way of compulsion and control, whether the means used be physical force in the form of legal penalties, or the moral coercion of public opinion. That principle is, that the sole end for which mankind are warranted, individually or collectively, in interfering with the liberty of action of any of their number, is self-protection. That the only purpose for which power can be rightfully exercised over any member of a civilised community, against his will, is to prevent harm to others. His own good, either physical or moral, is not a sufficient warrant. He cannot rightfully be compelled to do or forbear because it will be better for him to do so, because it will make him happier, because, in the opinions of others, to do so would be wise, or even right. These are good reasons for remonstrating with him, or reasoning with him, or persuading him, or entreating him, but not for compelling him, or visiting him with any evil in case he do otherwise. To justify that, the conduct from which it is desired to deter him must be calculated to produce evil to some one else. The only part of the conduct of any one, for which he is amenable to society, is that which concerns others. In the part which merely concerns himself, his independence is, of right, absolute. Over himself, over his own body and mind, the individual is sovereign.

It is, perhaps, hardly necessary to say that this doctrine is meant to 


\section{4/John Stuart Mill}

apply only to human beings in the maturity of their faculties. We are not speaking of children, or of young persons below the age which the law may fix as that of manhood or womanhood. Those who are still in a state to require being taken care of by others, must be protected against their own actions as well as against external injury. For the same reason, we may leave out of consideration those backward states of society in which the race itself may be considered as in its nonage. The early difficulties in the way of spontaneous progress are so great, that there is seldom any choice of means for overcoming them; and a ruler full of the spirit of improvement is warranted in the use of any expedients that will attain an end, perhaps otherwise unattainable. Despotism is a legitimate mode of government in dealing with barbarians, provided the end be their improvement, and the means justified by actually effecting that end. Liberty, as a principle, has no application to any state of things anterior to the time when mankind have become capable of being improved by free and equal discussion. Until then, there is nothing for them but implicit obedience to an Akbar or a Charlemagne, if they are so fortunate as to find one. But as soon as mankind have attained the capacity of being guided to their own improvement by conviction or persuasion (a period long since reached in all nations with whom we need here concern ourselves), compulsion, either in the direct form or in that of pains and penalties for non-compliance, is no longer admissible as a means to their own good, and justifiable only for the security of others.

It is proper to state that I forego any advantage which could be derived to my argument from the idea of abstract right, as a thing independent of utility. I regard utility as the ultimate appeal on all ethical questions; but it must be utility in the largest sense, grounded on the permanent interests of a man as a progressive being. Those interests, I contend, authorise the subjection of individual spontaneity to external control, only in respect to those actions of each, which concern the interest of other people. If any one does an act hurtful to others, there is a prima facie case for punishing him, by law, or, where legal penalties are not safely applicable, by general disapprobation. There are also many positive acts for the benefit of others, which he may rightfully be compelled to perform; such as to give evidence in a court of justice; to bear his fair share in the common defence, or in any other joint work necessary to the interest of the society of which he enjoys the protection; and to perform certain acts of individual beneficence, such as saving a fel- 
low creature's life, or interposing to protect the defenceless against illusage, things which whenever it is obviously a man's duty to do, he may rightfully be made responsible to society for not doing. A person may cause evil to others not only by his actions but by his inaction, and in either case he is justly accountable to them for the injury. The latter case, it is true, requires a much more cautious exercise of compulsion than the former. To make any one answerable for doing evil to others is the rule; to make him answerable for not preventing evil is, comparatively speaking, the exception. Yet there are many cases clear enough and grave enough to justify that exception. In all things which regard the external relations of the individual, he is de jure amenable to those whose interests are concerned, and, if need be, to society as their protector. There are often good reasons for not holding him to the responsibility; but these reasons must arise from the special expediencies of the case: either because it is a kind of case in which he is on the whole likely to act better, when left to his own discretion, than when controlled in any way in which society have it in their power to control him; or because the attempt to exercise control would produce other evils, greater than those which it would prevent. When such reasons as these preclude the enforcement of responsibility, the conscience of the agent himself should step into the vacant judgment seat, and protect those interests of others which have no external protection; judging himself all the more rigidly, because the case does not admit of his being made accountable to the judgment of his fellow creatures.

But there is a sphere of action in which society, as distinguished from the individual, has, if any, only an indirect interest; comprehending all that portion of a person's life and conduct which affects only himself, or if it also affects others, only with their free, voluntary, and undeceived consent and participation. When I say only himself, I mean directly, and in the first instance; for whatever affects himself, may affect others through himself; and the objection which may be grounded on this contingency, will receive consideration in the sequel. This, then, is the appropriate region of human liberty. It comprises, first, the inward domain of consciousness; demanding liberty of conscience in the most comprehensive sense; liberty of thought and feeling; absolute freedom of opinion and sentiment on all subjects, practical or speculative, scientific, moral, or theological. The liberty of expressing and publishing opinions may seem to fall under a different principle, since it belongs to that part of the conduct of an individual which concerns other 


\section{6/John Stuart Mill}

people; but, being almost of as much importance as the liberty of thought itself, and resting in great part on the same reasons, is practically inseparable from it. Secondly, the principle requires liberty of tastes and pursuits; of framing the plan of our life to suit our own character; of doing as we like, subject to such consequences as may follow: without impediment from our fellow creatures, so long as what we do does not harm them, even though they should think our conduct foolish, perverse, or wrong. Thirdly, from this liberty of each individual, follows the liberty, within the same limits, of combination among individuals; freedom to unite, for any purpose not involving harm to others: the persons combining being supposed to be of full age, and not forced or deceived.

No society in which these liberties are not, on the whole, respected, is free, whatever may be its form of government; and none is completely free in which they do not exist absolute and unqualified. The only freedom which deserves the name, is that of pursuing our own good in our own way, so long as we do not attempt to deprive others of theirs, or impede their efforts to obtain it. Each is the proper guardian of his own health, whether bodily, or mental and spiritual. Mankind are greater gainers by suffering each other to live as seems good to themselves, than by compelling each to live as seems good to the rest.

Though this doctrine is anything but new, and, to some persons, may have the air of a truism, there is no doctrine which stands more directly opposed to the general tendency of existing opinion and practice. Society has expended fully as much effort in the attempt (according to its lights) to compel people to conform to its notions of personal as of social excellence. The ancient commonwealths thought themselves entitled to practise, and the ancient philosophers countenanced, the regulation of every part of private conduct by public authority, on the ground that the State had a deep interest in the whole bodily and mental discipline of every one of its citizens; a mode of thinking which may have been admissible in small republics surrounded by powerful enemies, in constant peril of being subverted by foreign attack or internal commotion, and to which even a short interval of relaxed energy and self-command might so easily be fatal that they could not afford to wait for the salutary permanent effects of freedom. In the modern world, the greater size of political communities, and, above all, the separation between spiritual and temporal authority (which placed the direction of men's consciences in other hands than those which controlled their worldly 
affairs), prevented so great an interference by law in the details of private life; but the engines of moral repression have been wielded more strenuously against divergence from the reigning opinion in self-regarding, than even in social matters; religion, the most powerful of the elements which have entered into the formation of moral feeling, having almost always been governed either by the ambition of a hierarchy, seeking control over every department of human conduct, or by the spirit of Puritanism. And some of those modern reformers who have placed themselves in strongest opposition to the religions of the past, have been noway behind either churches or sects in their assertion of the right of spiritual domination: M. Comte, in particular, whose social system, as unfolded in his Système de Politique Positive, aims at establishing (though by moral more than by legal appliances) a despotism of society over the individual, surpassing anything contemplated in the political ideal of the most rigid disciplinarian among the ancient philosophers.

Apart from the peculiar tenets of individual thinkers, there is also in the world at large an increasing inclination to stretch unduly the powers of society over the individual, both by the force of opinion and even by that of legislation; and as the tendency of all the changes taking place in the world is to strengthen society, and diminish the power of the individual, this encroachment is not one of the evils which tend spontaneously to disappear, but, on the contrary, to grow more and more formidable. The disposition of mankind, whether as rulers or as fellow-citizens, to impose their own opinions and inclinations as a rule of conduct on others, is so energetically supported by some of the best and by some of the worst feelings incident to human nature, that it is hardly ever kept under restraint by anything but want of power; and as the power is not declining, but growing, unless a strong barrier of moral conviction can be raised against the mischief, we must expect, in the present circumstances of the world, to see it increase.

It will be convenient for the argument, if, instead of at once entering upon the general thesis, we confine ourselves in the first instance to a single branch of it, on which the principle here stated is, if not fully, yet to a certain point, recognised by the current opinions. This one branch is the Liberty of Thought: from which it is impossible to separate the cognate liberty of speaking and of writing. Although these liberties, to some considerable amount, form part of the political morality of all countries which profess religious toleration and free institutions, the grounds, both philosophical and practical, on which they rest, are perhaps not so fa- 


\section{8/John Stuart Mill}

miliar to the general mind, nor so thoroughly appreciated by many even of the leaders of opinion, as might have been expected. Those grounds, when rightly understood, are of much wider application than to only one division of the subject, and a thorough consideration of this part of the question will be found the best introduction to the remainder. Those to whom nothing which I am about to say will be new, may therefore, I hope, excuse me, if on a subject which for now three centuries has been so often discussed, I venture on one discussion more.

\section{Chapter 2. Of the Liberty of Thought and Discussion.}

The time, it is to be hoped, is gone by, when any defence would be necessary of the "liberty of the press" as one of the securities against corrupt or tyrannical government. No argument, we may suppose, can now be needed, against permitting a legislature or an executive, not identified in interest with the people, to prescribe opinions to them, and determine what doctrines or what arguments they shall be allowed to hear. This aspect of the question, besides, has been so of and so triumphantly enforced by preceding writers, that it needs not be specially insisted on in this place. Though the law of England, on the subject of the press, is as servile to this day as it was in the time of the Tudors, there is little danger of its being actually put in force against political discussion, except during some temporary panic, when fear of insurrection drives ministers and judges from their propriety; ${ }^{1}$ and, speaking generally, it is not, in constitutional countries, to be apprehended, that the government, whether completely responsible to the people or not, will often attempt to control the expression of opinion, except when in doing so it makes itself the organ of the general intolerance of the public. Let us suppose, therefore, that the government is entirely at one with the people, and never thinks of exerting any power of coercion unless in agreement with what it conceives to be their voice. But I deny the right of the people to exercise such coercion, either by themselves or by their government. The power itself is illegitimate. The best government has no more title to it than the worst. It is as noxious, or more noxious, when exerted in accordance with public opinion, than when in opposition to it. If all mankind minus one were of one opinion, and only one person were of the contrary opinion, mankind would be no more justified in silencing that one person, than he, if he had the power, would be justified in silencing mankind. Were an opinion a personal possession of no 
value except to the owner; if to be obstructed in the enjoyment of it were simply a private injury, it would make some difference whether the injury was inflicted only on a few persons or on many. But the peculiar evil of silencing the expression of an opinion is, that it is robbing the human race; posterity as well as the existing generation; those who dissent from the opinion, still more than those who hold it. If the opinion is right, they are deprived of the opportunity of exchanging error for truth: if wrong, they lose, what is almost as great a benefit, the clearer perception and livelier impression of truth, produced by its collision with error.

It is necessary to consider separately these two hypotheses, each of which has a distinct branch of the argument corresponding to it. We can never be sure that the opinion we are endeavouring to stifle is a false opinion; and if we were sure, stifling it would be an evil still.

First: the opinion which it is attempted to suppress by authority may possibly be true. Those who desire to suppress it, of course deny its truth; but they are not infallible. They have no authority to decide the question for all mankind, and exclude every other person from the means of judging. To refuse a hearing to an opinion, because they are sure that it is false, is to assume that their certainty is the same thing as absolute certainty. All silencing of discussion is an assumption of infallibility. Its condemnation may be allowed to rest on this common argument, not the worse for being common.

Unfortunately for the good sense of mankind, the fact of their fallibility is far from carrying the weight in their practical judgment which is always allowed to it in theory; for while every one well knows himself to be fallible, few think it necessary to take any precautions against their own fallibility, or admit the supposition that any opinion, of which they feel very certain, may be one of the examples of the error to which they acknowledge themselves to be liable. Absolute princes, or others who are accustomed to unlimited deference, usually feel this complete confidence in their own opinions on nearly all subjects. People more happily situated, who sometimes hear their opinions disputed, and are not wholly unused to be set right when they are wrong, place the same unbounded reliance only on such of their opinions as are shared by all who surround them, or to whom they habitually defer; for in proportion to a man's want of confidence in his own solitary judgment, does he usually repose, with implicit trust, on the infallibility of "the world" in general. And the world, to each individual, means the part of it with which he comes in contact; his party, his sect, his church, his class of 
society; the man may be called, by comparison, almost liberal and largeminded to whom it means anything so comprehensive as his own country or his own age. Nor is his faith in this collective authority at all shaken by his being aware that other ages, countries, sects, churches, classes, and parties have thought, and even now think, the exact reverse. He devolves upon his own world the responsibility of being in the right against the dissentient worlds of other people; and it never troubles him that mere accident has decided which of these numerous worlds is the object of his reliance, and that the same causes which make him a Churchman in London, would have made him a Buddhist or a Confucian in Pekin. Yet it is as evident in itself, as any amount of argument can make it, that ages are no more infallible than individuals; every age having held many opinions which subsequent ages have deemed not only false but absurd; and it is as certain that many opinions now general will be rejected by future ages, as it is that many, once general, are rejected by the present.

The objection likely to be made to this argument would probably take some such form as the following. There is no greater assumption of infallibility in forbidding the propagation of error, than in any other thing which is done by public authority on its own judgment and responsibility. Judgment is given to men that they may use it. Because it may be used erroneously, are men to be told that they ought not to use it at all? To prohibit what they think pernicious, is not claiming exemption from error, but fulfilling the duty incumbent on them, although fallible, of acting on their conscientious conviction. If we were never to act on our opinions, because those opinions may be wrong, we should leave all our interests uncared for, and all our duties unperformed. An objection which applies to all conduct can be no valid objection to any conduct in particular. It is the duty of governments, and of individuals, to form the truest opinions they can; to form them carefully, and never impose them upon others unless they are quite sure of being right. But when they are sure (such reasoners may say), it is not conscientiousness but cowardice to shrink from acting on their opinions, and allow doctrines which they honestly think dangerous to the welfare of mankind, either in this life or in another, to be scattered abroad without restraint, because other people, in less enlightened times, have persecuted opinions now believed to be true. Let us take care, it may be said, not to make the same mistake: but governments and nations have made mistakes in other things, which are not denied to be fit subjects for the exercise of authority: they have laid 
on bad taxes, made unjust wars. Ought we therefore to lay on no taxes, and, under whatever provocation, make no wars? Men, and governments, must act to the best of their ability. There is no such thing as absolute certainty, but there is assurance sufficient for the purposes of human life. We may, and must, assume our opinion to be true for the guidance of our own conduct: and it is assuming no more when we forbid bad men to pervert society by the propagation of opinions which we regard as false and pernicious.

I answer, that it is assuming very much more. There is the greatest difference between presuming an opinion to be true, because, with every opportunity for contesting it, it has not been refuted, and assuming its truth for the purpose of not permitting its refutation. Complete liberty of contradicting and disproving our opinion is the very condition which justifies us in assuming its truth for purposes of action; and on no other terms can a being with human faculties have any rational assurance of being right.

When we consider either the history of opinion, or the ordinary conduct of human life, to what is it to be ascribed that the one and the other are no worse than they are? Not certainly to the inherent force of the human understanding; for, on any matter not self-evident, there are ninety-nine persons totally incapable of judging of it for one who is capable; and the capacity of the hundredth person is only comparative; for the majority of the eminent men of every past generation held many opinions now known to be erroneous, and did or approved numerous things which no one will now justify. Why is it, then, that there is on the whole a preponderance among mankind of rational opinions and rational conduct? If there really is this preponderance-which there must be unless human affairs are, and have always been, in an almost desperate state-it is owing to a quality of the human mind, the source of everything respectable in man either as an intellectual or as a moral being, namely, that his errors are corrigible. He is capable of rectifying his mistakes, by discussion and experience. Not by experience alone. There must be discussion, to show how experience is to be interpreted. Wrong opinions and practices gradually yield to fact and argument; but facts and arguments, to produce any effect on the mind, must be brought before it. Very few facts are able to tell their own story, without comments to bring out their meaning. The whole strength and value, then, of human judgment, depending on the one property, that it can be set right when it is wrong, reliance can be placed on it only when the means of 


\section{2/John Stuart Mill}

setting it right are kept constantly at hand. In the case of any person whose judgment is really deserving of confidence, how has it become so? Because he has kept his mind open to criticism of his opinions and conduct. Because it has been his practice to listen to all that could be said against him; to profit by as much of it as was just, and expound to himself, and upon occasion to others, the fallacy of what was fallacious. Because he has felt, that the only way in which a human being can make some approach to knowing the whole of a subject, is by hearing what can be said about it by persons of every variety of opinion, and studying all modes in which it can be looked at by every character of mind. No wise man ever acquired his wisdom in any mode but this; nor is it in the nature of human intellect to become wise in any other manner. The steady habit of correcting and completing his own opinion by collating it with those of others, so far from causing doubt and hesitation in carrying it into practice, is the only stable foundation for a just reliance on it: for, being cognisant of all that can, at least obviously, be said against him, and having taken up his position against all gainsayers-knowing that he has sought for objections and difficulties, instead of avoiding them, and has shut out no light which can be thrown upon the subject from any quarter-he has a right to think his judgment better than that of any person, or any multitude, who have not gone through a similar process.

It is not too much to require that what the wisest of mankind, those who are best entitled to trust their own judgment, find necessary to warrant their relying on it, should be submitted to by that miscellaneous collection of a few wise and many foolish individuals, called the public. The most intolerant of churches, the Roman Catholic Church, even at the canonisation of a saint, admits, and listens patiently to, a "devil's advocate." The holiest of men, it appears, cannot be admitted to posthumous honours, until all that the devil could say against him is known and weighed. If even the Newtonian philosophy were not permitted to be questioned, mankind could not feel as complete assurance of its truth as they now do. The beliefs which we have most warrant for have no safeguard to rest on, but a standing invitation to the whole world to prove them unfounded. If the challenge is not accepted, or is accepted and the attempt fails, we are far enough from certainty still; but we have done the best that the existing state of human reason admits of; we have neglected nothing that could give the truth a chance of reaching us: if the lists are kept open, we may hope that if there be a better truth, it will be found when the human mind is capable of receiving it; and in the mean- 
time we may rely on having attained such approach to truth as is possible in our own day. This is the amount of certainty attainable by a fallible being, and this the sole way of attaining it.

Strange it is, that men should admit the validity of the arguments for free discussion, but object to their being "pushed to an extreme"; not seeing that unless the reasons are good for an extreme case, they are not good for any case. Strange that they should imagine that they are not assuming infallibility, when they acknowledge that there should be free discussion on all subjects which can possibly be doubtful, but think that some particular principle or doctrine should be forbidden to be questioned because it is so certain, that is, because they are certain that it is certain. To call any proposition certain, while there is any one who would deny its certainty if permitted, but who is not permitted, is to assume that we ourselves, and those who agree with us, are the judges of certainty, and judges without hearing the other side.

In the present age - which has been described as "destitute of faith, but terrified at scepticism"-in which people feel sure, not so much that their opinions are true, as that they should not know what to do without them- the claims of an opinion to be protected from public attack are rested not so much on its truth, as on its importance to society. There are, it is alleged, certain beliefs so useful, not to say indispensable, to well-being that it is as much the duty of governments to uphold those beliefs, as to protect any other of the interests of society. In a case of such necessity, and so directly in the line of their duty, something less than infallibility may, it is maintained, warrant, and even bind, governments to act on their own opinion, confirmed by the general opinion of mankind. It is also often argued, and still oftener thought, that none but bad men would desire to weaken these salutary beliefs; and there can be nothing wrong, it is thought, in restraining bad men, and prohibiting what only such men would wish to practise. This mode of thinking makes the justification of restraints on discussion not a question of the truth of doctrines, but of their usefulness; and flatters itself by that means to escape the responsibility of claiming to be an infallible judge of opinions.

But those who thus satisfy themselves, do not perceive that the assumption of infallibility is merely shifted from one point to another. The usefulness of an opinion is itself matter of opinion: as disputable, as open to discussion, and requiring discussion as much as the opinion itself. There is the same need of an infallible judge of opinions to decide 


\section{4/John Stuart Mill}

an opinion to be noxious, as to decide it to be false, unless the opinion condemned has full opportunity of defending itself. And it will not do to say that the heretic may be allowed to maintain the utility or harmlessness of his opinion, though forbidden to maintain its truth. The truth of an opinion is part of its utility. If we would know whether or not it is desirable that a proposition should be believed, is it possible to exclude the consideration of whether or not it is true? In the opinion, not of bad men, but of the best men, no belief which is contrary to truth can be really useful: and can you prevent such men from urging that plea, when they are charged with culpability for denying some doctrine which they are told is useful, but which they believe to be false? Those who are on the side of received opinions never fail to take all possible advantage of this plea; you do not find them handling the question of utility as if it could be completely abstracted from that of truth: on the contrary, it is, above all, because their doctrine is "the truth," that the knowledge or the belief of it is held to be so indispensable. There can be no fair discussion of the question of usefulness when an argument so vital may be employed on one side, but not on the other. And in point of fact, when law or public feeling do not permit the truth of an opinion to be disputed, they are just as little tolerant of a denial of its usefulness. The utmost they allow is an extenuation of its absolute necessity, or of the positive guilt of rejecting it.

In order more fully to illustrate the mischief of denying a hearing to opinions because we, in our own judgment, have condemned them, it will be desirable to fix down the discussion to a concrete case; and I choose, by preference, the cases which are least favourable to me-in which the argument against freedom of opinion, both on the score of truth and on that of utility, is considered the strongest. Let the opinions impugned be the belief in a God and in a future state, or any of the commonly received doctrines of morality. To fight the battle on such ground gives a great advantage to an unfair antagonist; since he will be sure to say (and many who have no desire to be unfair will say it internally), Are these the doctrines which you do not deem sufficiently certain to be taken under the protection of law? Is the belief in a God one of the opinions to feel sure of which you hold to be assuming infallibility? But I must be permitted to observe, that it is not the feeling sure of a doctrine (be it what it may) which I call an assumption of infallibility. It is the undertaking to decide that question for others, without allowing them to hear what can be said on the contrary side. And I denounce and 
reprobate this pretension not the less, if put forth on the side of my most solemn convictions. However positive any one's persuasion may be, not only of the falsity but of the pernicious consequences-not only of the pernicious consequences, but (to adopt expressions which I altogether condemn) the immorality and impiety of an opinion; yet if, in pursuance of that private judgment, though backed by the public judgment of his country or his contemporaries, he prevents the opinion from being heard in its defence, he assumes infallibility. And so far from the assumption being less objectionable or less dangerous because the opinion is called immoral or impious, this is the case of all others in which it is most fatal. These are exactly the occasions on which the men of one generation commit those dreadful mistakes which excite the astonishment and horror of posterity. It is among such that we find the instances memorable in history, when the arm of the law has been employed to root out the best men and the noblest doctrines; with deplorable success as to the men, though some of the doctrines have survived to be (as if in mockery) invoked in defence of similar conduct towards those who dissent from them, or from their received interpretation.

Mankind can hardly be too often reminded, that there was once a man named Socrates, between whom and the legal authorities and public opinion of his time there took place a memorable collision. Born in an age and country abounding in individual greatness, this man has been handed down to us by those who best knew both him and the age, as the most virtuous man in it; while we know him as the head and prototype of all subsequent teachers of virtue, the source equally of the lofty inspiration of Plato and the judicious utilitarianism of Aristotle, "i mastri di color che sanno," the two headsprings of ethical as of all other philosophy. This acknowledged master of all the eminent thinkers who have since lived-whose fame, still growing after more than two thousand years, all but outweighs the whole remainder of the names which make his native city illustrious-was put to death by his countrymen, after a judicial conviction, for impiety and immorality. Impiety, in denying the gods recognised by the State; indeed his accuser asserted (see the Apologia) that he believed in no gods at all. Immorality, in being, by his doctrines and instructions, a "corruptor of youth." Of these charges the tribunal, there is every ground for believing, honestly found him guilty, and condemned the man who probably of all then born had deserved best of mankind to be put to death as a criminal.

To pass from this to the only other instance of judicial iniquity, the 
mention of which, after the condemnation of Socrates, would not be an anti-climax: the event which took place on Calvary rather more than eighteen hundred years ago. The man who left on the memory of those who witnessed his life and conversation such an impression of his moral grandeur that eighteen subsequent centuries have done homage to him as the Almighty in person, was ignominiously put to death, as what? As a blasphemer. Men did not merely mistake their benefactor; they mistook him for the exact contrary of what he was, and treated him as that prodigy of impiety which they themselves are now held to be for their treatment of him. The feelings with which mankind now regard these lamentable transactions, especially the later of the two, render them extremely unjust in their judgment of the unhappy actors. These were, to all appearance, not bad men-not worse than men commonly are, but rather the contrary; men who possessed in a full, or somewhat more than a full measure, the religious, moral, and patriotic feelings of their time and people: the very kind of men who, in all times, our own included, have every chance of passing through life blameless and respected. The high-priest who rent his garments when the words were pronounced, which, according to all the ideas of his country, constituted the blackest guilt, was in all probability quite as sincere in his horror and indignation as the generality of respectable and pious men now are in the religious and moral sentiments they profess; and most of those who now shudder at his conduct, if they had lived in his time, and been born Jews, would have acted precisely as he did. Orthodox Christians who are tempted to think that those who stoned to death the first martyrs must have been worse men than they themselves are, ought to remember that one of those persecutors was Saint Paul.

Let us add one more example, the most striking of all, if the impressiveness of an error is measured by the wisdom and virtue of him who falls into it. If ever any one, possessed of power, had grounds for thinking himself the best and most enlightened among his contemporaries, it was the Emperor Marcus Aurelius. Absolute monarch of the whole civilised world, he preserved through life not only the most unblemished justice, but what was less to be expected from his Stoical breeding, the tenderest heart. The few failings which are attributed to him were all on the side of indulgence: while his writings, the highest ethical product of the ancient mind, differ scarcely perceptibly, if they differ at all, from the most characteristic teachings of Christ. This man, a better Christian in all but the dogmatic sense of the word than almost any of the ostensi- 
bly Christian sovereigns who have since reigned, persecuted Christianity. Placed at the summit of all the previous attainments of humanity, with an open, unfettered intellect, and a character which led him of himself to embody in his moral writings the Christian ideal, he yet failed to see that Christianity was to be a good and not an evil to the world, with his duties to which he was so deeply penetrated. Existing society he knew to be in a deplorable state. But such as it was, he saw, or thought he saw, that it was held together, and prevented from being worse, by belief and reverence of the received divinities. As a ruler of mankind, he deemed it his duty not to suffer society to fall in pieces; and saw not how, if its existing ties were removed, any others could be formed which could again knit it together. The new religion openly aimed at dissolving these ties: unless, therefore, it was his duty to adopt that religion, it seemed to be his duty to put it down. Inasmuch then as the theology of Christianity did not appear to him true or of divine origin; inasmuch as this strange history of a crucified God was not credible to him, and a system which purported to rest entirely upon a foundation to him so wholly unbelievable, could not be foreseen by him to be that renovating agency which, after all abatements, it has in fact proved to be; the gentlest and most amiable of philosophers and rulers, under a solemn sense of duty, authorised the persecution of Christianity.

To my mind this is one of the most tragical facts in all history. It is a bitter thought, how different a thing the Christianity of the world might have been, if the Christian faith had been adopted as the religion of the empire under the auspices of Marcus Aurelius instead of those of Constantine. But it would be equally unjust to him and false to truth to deny, that no one plea which can be urged for punishing anti-Christian teaching was wanting to Marcus Aurelius for punishing, as he did, the propagation of Christianity. No Christian more firmly believes that Atheism is false, and tends to the dissolution of society, than Marcus Aurelius believed the same things of Christianity; he who, of all men then living, might have been thought the most capable of appreciating it. Unless any one who approves of punishment for the promulgation of opinions, flatters himself that he is a wiser and better man than Marcus Aureliusmore deeply versed in the wisdom of his time, more elevated in his intellect above it - more earnest in his search for truth, or more single-minded in his devotion to it when found; let him abstain from that assumption of the joint infallibility of himself and the multitude, which the great Antoninus made with so unfortunate a result. 
Aware of the impossibility of defending the use of punishment for restraining irreligious opinions by any argument which will not justify Marcus Antoninus, the enemies of religious freedom, when hard pressed, occasionally accept this consequence, and say, with Dr. Johnson, that the persecutors of Christianity were in the right; that persecution is an ordeal through which truth ought to pass, and always passes successfully, legal penalties being, in the end, powerless against truth, though sometimes beneficially effective against mischievous errors. This is a form of the argument for religious intolerance sufficiently remarkable not to be passed without notice.

A theory which maintains that truth may justifiably be persecuted because persecution cannot possibly do it any harm, cannot be charged with being intentionally hostile to the reception of new truths; but we cannot commend the generosity of its dealing with the persons to whom mankind are indebted for them. To discover to the world something which deeply concerns it, and of which it was previously ignorant; to prove to it that it had been mistaken on some vital point of temporal or spiritual interest, is as important a service as a human being can render to his fellow creatures, and in certain cases, as in those of the early Christians and of the Reformers, those who think with Dr. Johnson believe it to have been the most precious gift which could be bestowed on mankind. That the authors of such splendid benefits should be requited by martyrdom; that their reward should be to be dealt with as the vilest of criminals, is not, upon this theory, a deplorable error and misfortune, for which humanity should mourn in sackcloth and ashes, but the normal and justifiable state of things. The propounder of a new truth, according to this doctrine, should stand as stood, in the legislation of the Locrians, the proposer of a new law, with a halter round his neck, to be instantly tightened if the public assembly did not, on hearing his reasons, then and there adopt his proposition. People who defend this mode of treating benefactors cannot be supposed to set much value on the benefit; and I believe this view of the subject is mostly confined to the sort of persons who think that new truths may have been desirable once, but that we have had enough of them now.

But, indeed, the dictum that truth always triumphs over persecution is one of those pleasant falsehoods which men repeat after one another till they pass into commonplaces, but which all experience refutes. History teems with instances of truth put down by persecution. If not suppressed for ever, it may be thrown back for centuries. To speak only of 
religious opinions: the Reformation broke out at least twenty times before Luther, and was put down. Arnold of Brescia was put down. Fra Dolcino was put down. Savonarola was put down. The Albigeois were put down. The Vaudois were put down. The Lollards were put down. The Hussites were put down. Even after the era of Luther, wherever persecution was persisted in, it was successful. In Spain, Italy, Flanders, the Austrian empire, Protestantism was rooted out; and, most likely, would have been so in England, had Queen Mary lived, or Queen Elizabeth died. Persecution has always succeeded, save where the heretics were too strong a party to be effectually persecuted. No reasonable person can doubt that Christianity might have been extirpated in the Roman Empire. It spread, and became predominant, because the persecutions were only occasional, lasting but a short time, and separated by long intervals of almost undisturbed propagandism. It is a piece of idle sentimentality that truth, merely as truth, has any inherent power denied to error of prevailing against the dungeon and the stake. Men are not more zealous for truth than they often are for error, and a sufficient application of legal or even of social penalties will generally succeed in stopping the propagation of either. The real advantage which truth has consists in this, that when an opinion is true, it may be extinguished once, twice, or many times, but in the course of ages there will generally be found persons to rediscover it, until some one of its reappearances falls on a time when from favourable circumstances it escapes persecution until it has made such head as to withstand all subsequent attempts to suppress it.

It will be said, that we do not now put to death the introducers of new opinions: we are not like our fathers who slew the prophets, we even build sepulchres to them. It is true we no longer put heretics to death; and the amount of penal infliction which modern feeling would probably tolerate, even against the most obnoxious opinions, is not sufficient to extirpate them. But let us not flatter ourselves that we are yet free from the stain even of legal persecution. Penalties for opinion, or at least for its expression, still exist by law; and their enforcement is not, even in these times, so unexampled as to make it at all incredible that they may some day be revived in full force. In the year 1857, at the summer assizes of the county of Cornwall, an unfortunate man, ${ }^{2}$ said to be of unexceptionable conduct in all relations of life, was sentenced to twenty-one months' imprisonment, for uttering, and writing on a gate, some offensive words concerning Christianity. Within a month of the 
same time, at the Old Bailey, two persons, on two separate occasions, ${ }^{3}$ were rejected as jurymen, and one of them grossly insulted by the judge and by one of the counsel, because they honestly declared that they had no theological belief; and a third, a foreigner, ${ }^{4}$ for the same reason, was denied justice against a thief.

This refusal of redress took place in virtue of the legal doctrine, that no person can be allowed to give evidence in a court of justice who does not profess belief in a God (any god is sufficient) and in a future state; which is equivalent to declaring such persons to be outlaws, excluded from the protection of the tribunals; who may not only be robbed or assaulted with impunity, if no one but themselves, or persons of similar opinions, be present, but any one else may be robbed or assaulted with impunity, if the proof of the fact depends on their evidence. The assumption on which this is grounded is that the oath is worthless of a person who does not believe in a future state; a proposition which betokens much ignorance of history in those who assent to it (since it is historically true that a large proportion of infidels in all ages have been persons of distinguished integrity and honour); and would be maintained by no one who had the smallest conception how many of the persons in greatest repute with the world, both for virtues and attainments, are well known, at least to their intimates, to be unbelievers. The rule, besides, is suicidal, and cuts away its own foundation. Under pretence that atheists must be liars, it admits the testimony of all atheists who are willing to lie, and rejects only those who brave the obloquy of publicly confessing a detested creed rather than affirm a falsehood. A rule thus self-convicted of absurdity so far as regards its professed purpose, can be kept in force only as a badge of hatred, a relic of persecution; a persecution, too, having the peculiarity that the qualification for undergoing it is the being clearly proved not to deserve it. The rule, and the theory it implies, are hardly less insulting to believers than to infidels. For if he who does not believe in a future state necessarily lies, it follows that they who do believe are only prevented from lying, if prevented they are, by the fear of hell. We will not do the authors and abettors of the rule the injury of supposing that the conception which they have formed of Christian virtue is drawn from their own consciousness.

These, indeed, are but rags and remnants of persecution, and may be thought to be not so much an indication of the wish to persecute, as an example of that very frequent infirmity of English minds, which makes them take a preposterous pleasure in the assertion of a bad principle, 
when they are no longer bad enough to desire to carry it really into practice. But unhappily there is no security in the state of the public mind that the suspension of worse forms of legal persecution, which has lasted for about the space of a generation, will continue. In this age the quiet surface of routine is as often ruffled by attempts to resuscitate past evils, as to introduce new benefits. What is boasted of at the present time as the revival of religion, is always, in narrow and uncultivated minds, at least as much the revival of bigotry; and where there is the strong permanent leaven of intolerance in the feelings of a people, which at all times abides in the middle classes of this country, it needs but little to provoke them into actively persecuting those whom they have never ceased to think proper objects of persecution. ${ }^{5}$ For it is this-it is the opinions men entertain, and the feelings they cherish, respecting those who disown the beliefs they deem important, which makes this country not a place of mental freedom.

For a long time past, the chief mischief of the legal penalties is that they strengthen the social stigma. It is that stigma which is really effective, and so effective is it, that the profession of opinions which are under the ban of society is much less common in England than is, in many other countries, the avowal of those which incur risk of judicial punishment. In respect to all persons but those whose pecuniary circumstances make them independent of the good will of other people, opinion, on this subject, is as efficacious as law; men might as well be imprisoned, as excluded from the means of earning their bread. Those whose bread is already secured, and who desire no favours from men in power, or from bodies of men, or from the public, have nothing to fear from the open avowal of any opinions, but to be ill-thought of and illspoken of, and this it ought not to require a very heroic mould to enable them to bear. There is no room for any appeal ad misericordiam in behalf of such persons. But though we do not now inflict so much evil on those who think differently from us as it was formerly our custom to do, it may be that we do ourselves as much evil as ever by our treatment of them. Socrates was put to death, but the Socratic philosophy rose like the sun in heaven, and spread its illumination over the whole intellectual firmament. Christians were cast to the lions, but the Christian church grew up a stately and spreading tree, overtopping the older and less vigorous growths, and stifling them by its shade. Our merely social intolerance kills no one, roots out no opinions, but induces men to disguise them, or to abstain from any active effort for their diffusion. With 
us, heretical opinions do not perceptibly gain, or even lose, ground in each decade or generation; they never blaze out far and wide, but continue to smoulder in the narrow circles of thinking and studious persons among whom they originate, without ever lighting up the general affairs of mankind with either a true or a deceptive light.

And thus is kept up a state of things very satisfactory to some minds, because, without the unpleasant process of fining or imprisoning anybody, it maintains all prevailing opinions outwardly undisturbed, while it does not absolutely interdict the exercise of reason by dissentients afflicted with the malady of thought. A convenient plan for having peace in the intellectual world, and keeping all things going on therein very much as they do already. But the price paid for this sort of intellectual pacification is the sacrifice of the entire moral courage of the human mind. A state of things in which a large portion of the most active and inquiring intellects find it advisable to keep the general principles and grounds of their convictions within their own breasts, and attempt, in what they address to the public, to fit as much as they can of their own conclusions to premises which they have internally renounced, cannot send forth the open, fearless characters, and logical, consistent intellects who once adorned the thinking world. The sort of men who can be looked for under it, are either mere conformers to commonplace, or time-servers for truth, whose arguments on all great subjects are meant for their hearers, and are not those which have convinced themselves. Those who avoid this alternative, do so by narrowing their thoughts and interests to things which can be spoken of without venturing within the region of principles, that is, to small practical matters, which would come right of themselves, if but the minds of mankind were strengthened and enlarged, and which will never be made effectually right until then: while that which would strengthen and enlarge men's minds, free and daring speculation on the highest subjects, is abandoned.

Those in whose eyes this reticence on the part of heretics is no evil should consider, in the first place, that in consequence of it there is never any fair and thorough discussion of heretical opinions; and that such of them as could not stand such a discussion, though they may be prevented from spreading, do not disappear. But it is not the minds of heretics that are deteriorated most by the ban placed on all inquiry which does not end in the orthodox conclusions. The greatest harm done is to those who are not heretics, and whose whole mental development is cramped, and their reason cowed, by the fear of heresy. Who can com- 
pute what the world loses in the multitude of promising intellects combined with timid characters, who dare not follow out any bold, vigorous, independent train of thought, lest it should land them in something which would admit of being considered irreligious or immoral? Among them we may occasionally see some man of deep conscientiousness, and subtle and refined understanding, who spends a life in sophisticating with an intellect which he cannot silence, and exhausts the resources of ingenuity in attempting to reconcile the promptings of his conscience and reason with orthodoxy, which yet he does not, perhaps, to the end succeed in doing.

No one can be a great thinker who does not recognise, that as a thinker it is his first duty to follow his intellect to whatever conclusions it may lead. Truth gains more even by the errors of one who, with due study and preparation, thinks for himself, than by the true opinions of those who only hold them because they do not suffer themselves to think. Not that it is solely, or chiefly, to form great thinkers, that freedom of thinking is required. On the contrary, it is as much and even more indispensable to enable average human beings to attain the mental stature which they are capable of. There have been, and may again be, great individual thinkers in a general atmosphere of mental slavery. But there never has been, nor ever will be, in that atmosphere an intellectually active people. Where any people has made a temporary approach to such a character, it has been because the dread of heterodox speculation was for a time suspended. Where there is a tacit convention that principles are not to be disputed; where the discussion of the greatest questions which can occupy humanity is considered to be closed, we cannot hope to find that generally high scale of mental activity which has made some periods of history so remarkable. Never when controversy avoided the subjects which are large and important enough to kindle enthusiasm, was the mind of a people stirred up from its foundations, and the impulse given which raised even persons of the most ordinary intellect to something of the dignity of thinking beings. Of such we have had an example in the condition of Europe during the times immediately following the Reformation; another, though limited to the Continent and to a more cultivated class, in the speculative movement of the latter half of the eighteenth century; and a third, of still briefer duration, in the intellectual fermentation of Germany during the Goethian and Fichtean period. These periods differed widely in the particular opinions which they developed; but were alike in this, that during all three the yoke of au- 


\section{4/John Stuart Mill}

thority was broken. In each, an old mental despotism had been thrown off, and no new one had yet taken its place. The impulse given at these three periods has made Europe what it now is. Every single improvement which has taken place either in the human mind or in institutions, may be traced distinctly to one or other of them. Appearances have for some time indicated that all three impulses are well nigh spent; and we can expect no fresh start until we again assert our mental freedom.

Let us now pass to the second division of the argument, and dismissing the supposition that any of the received opinions may be false, let us assume them to be true, and examine into the worth of the manner in which they are likely to be held, when their truth is not freely and openly canvassed. However unwillingly a person who has a strong opinion may admit the possibility that his opinion may be false, he ought to be moved by the consideration that, however true it may be, if it is not fully, frequently, and fearlessly discussed, it will be held as a dead dogma, not a living truth.

There is a class of persons (happily not quite so numerous as formerly) who think it enough if a person assents undoubtingly to what they think true, though he has no knowledge whatever of the grounds of the opinion, and could not make a tenable defence of it against the most superficial objections. Such persons, if they can once get their creed taught from authority, naturally think that no good, and some harm, comes of its being allowed to be questioned. Where their influence prevails, they make it nearly impossible for the received opinion to be rejected wisely and considerately, though it may still be rejected rashly and ignorantly; for to shut out discussion entirely is seldom possible, and when it once gets in, beliefs not grounded on conviction are apt to give way before the slightest semblance of an argument. Waiving, however, this possibility - assuming that the true opinion abides in the mind, but abides as a prejudice, a belief independent of, and proof against, argument - this is not the way in which truth ought to be held by a rational being. This is not knowing the truth. Truth, thus held, is but one superstition the more, accidentally clinging to the words which enunciate a truth.

If the intellect and judgment of mankind ought to be cultivated, a thing which Protestants at least do not deny, on what can these faculties be more appropriately exercised by any one, than on the things which concern him so much that it is considered necessary for him to hold opinions on them? If the cultivation of the understanding consists in one 
thing more than in another, it is surely in learning the grounds of one's own opinions. Whatever people believe, on subjects on which it is of the first importance to believe rightly, they ought to be able to defend against at least the common objections. But, some one may say, "Let them be taught the grounds of their opinions. It does not follow that opinions must be merely parroted because they are never heard controverted. Persons who learn geometry do not simply commit the theorems to memory, but understand and learn likewise the demonstrations; and it would be absurd to say that they remain ignorant of the grounds of geometrical truths, because they never hear any one deny, and attempt to disprove them." Undoubtedly: and such teaching suffices on a subject like mathematics, where there is nothing at all to be said on the wrong side of the question. The peculiarity of the evidence of mathematical truths is that all the argument is on one side. There are no objections, and no answers to objections. But on every subject on which difference of opinion is possible, the truth depends on a balance to be struck between two sets of conflicting reasons. Even in natural philosophy, there is always some other explanation possible of the same facts; some geocentric theory instead of heliocentric, some phlogiston instead of oxygen; and it has to be shown why that other theory cannot be the true one: and until this is shown, and until we know how it is shown, we do not understand the grounds of our opinion.

But when we turn to subjects infinitely more complicated, to morals, religion, politics, social relations, and the business of life, threefourths of the arguments for every disputed opinion consist in dispelling the appearances which favour some opinion different from it. The greatest orator, save one, of antiquity, has left it on record that he always studied his adversary's case with as great, if not still greater, intensity than even his own. What Cicero practised as the means of forensic success requires to be imitated by all who study any subject in order to arrive at the truth. He who knows only his own side of the case, knows little of that. His reasons may be good, and no one may have been able to refute them. But if he is equally unable to refute the reasons on the opposite side; if he does not so much as know what they are, he has no ground for preferring either opinion. The rational position for him would be suspension of judgment, and unless he contents himself with that, he is either led by authority, or adopts, like the generality of the world, the side to which he feels most inclination. Nor is it enough that he should hear the arguments of adversaries from his own teachers, presented as 


\section{6/John Stuart Mill}

they state them, and accompanied by what they offer as refutations. That is not the way to do justice to the arguments, or bring them into real contact with his own mind. He must be able to hear them from persons who actually believe them; who defend them in earnest, and do their very utmost for them. He must know them in their most plausible and persuasive form; he must feel the whole force of the difficulty which the true view of the subject has to encounter and dispose of; else he will never really possess himself of the portion of truth which meets and removes that difficulty.

Ninety-nine in a hundred of what are called educated men are in this condition; even of those who can argue fluently for their opinions. Their conclusion may be true, but it might be false for anything they know: they have never thrown themselves into the mental position of those who think differently from them, and considered what such persons may have to say; and consequently they do not, in any proper sense of the word, know the doctrine which they themselves profess. They do not know those parts of it which explain and justify the remainder; the considerations which show that a fact which seemingly conflicts with another is reconcilable with it, or that, of two apparently strong reasons, one and not the other ought to be preferred. All that part of the truth which turns the scale, and decides the judgment of a completely informed mind, they are strangers to; nor is it ever really known, but to those who have attended equally and impartially to both sides, and endeavoured to see the reasons of both in the strongest light. So essential is this discipline to a real understanding of moral and human subjects, that if opponents of all important truths do not exist, it is indispensable to imagine them, and supply them with the strongest arguments which the most skilful devil's advocate can conjure up.

To abate the force of these considerations, an enemy of free discussion may be supposed to say, that there is no necessity for mankind in general to know and understand all that can be said against or for their opinions by philosophers and theologians. That it is not needful for common men to be able to expose all the misstatements or fallacies of an ingenious opponent. That it is enough if there is always somebody capable of answering them, so that nothing likely to mislead uninstructed persons remains unrefuted. That simple minds, having been taught the obvious grounds of the truths inculcated on them, may trust to authority for the rest, and being aware that they have neither knowledge nor talent to resolve every difficulty which can be raised, may repose in the assur- 
ance that all those which have been raised have been or can be answered, by those who are specially trained to the task.

Conceding to this view of the subject the utmost that can be claimed for it by those most easily satisfied with the amount of understanding of truth which ought to accompany the belief of it; even so, the argument for free discussion is no way weakened. For even this doctrine acknowledges that mankind ought to have a rational assurance that all objections have been satisfactorily answered; and how are they to be answered if that which requires to be answered is not spoken? or how can the answer be known to be satisfactory, if the objectors have no opportunity of showing that it is unsatisfactory? If not the public, at least the philosophers and theologians who are to resolve the difficulties, must make themselves familiar with those difficulties in their most puzzling form; and this cannot be accomplished unless they are freely stated, and placed in the most advantageous light which they admit of. The Catholic Church has its own way of dealing with this embarrassing problem. It makes a broad separation between those who can be permitted to receive its doctrines on conviction, and those who must accept them on trust. Neither, indeed, are allowed any choice as to what they will accept; but the clergy, such at least as can be fully confided in, may admissibly and meritoriously make themselves acquainted with the arguments of opponents, in order to answer them, and may, therefore, read heretical books; the laity, not unless by special permission, hard to be obtained. This discipline recognises a knowledge of the enemy's case as beneficial to the teachers, but finds means, consistent with this, of denying it to the rest of the world: thus giving to the elite more mental culture, though not more mental freedom, than it allows to the mass. By this device it succeeds in obtaining the kind of mental superiority which its purposes require; for though culture without freedom never made a large and liberal mind, it can make a clever nisi prius advocate of a cause. But in countries professing Protestantism, this resource is denied; since Protestants hold, at least in theory, that the responsibility for the choice of a religion must be borne by each for himself, and cannot be thrown off upon teachers. Besides, in the present state of the world, it is practically impossible that writings which are read by the instructed can be kept from the uninstructed. If the teachers of mankind are to be cognisant of all that they ought to know, everything must be free to be written and published without restraint.

If, however, the mischievous operation of the absence of free dis- 
cussion, when the received opinions are true, were confined to leaving men ignorant of the grounds of those opinions, it might be thought that this, if an intellectual, is no moral evil, and does not affect the worth of the opinions, regarded in their influence on the character. The fact, however, is, that not only the grounds of the opinion are forgotten in the absence of discussion, but too often the meaning of the opinion itself. The words which convey it cease to suggest ideas, or suggest only a small portion of those they were originally employed to communicate. Instead of a vivid conception and a living belief, there remain only a few phrases retained by rote; or, if any part, the shell and husk only of the meaning is retained, the finer essence being lost. The great chapter in human history which this fact occupies and fills, cannot be too earnestly studied and meditated on.

It is illustrated in the experience of almost all ethical doctrines and religious creeds. They are all full of meaning and vitality to those who originate them, and to the direct disciples of the originators. Their meaning continues to be felt in undiminished strength, and is perhaps brought out into even fuller consciousness, so long as the struggle lasts to give the doctrine or creed an ascendancy over other creeds. At last it either prevails, and becomes the general opinion, or its progress stops; it keeps possession of the ground it has gained, but ceases to spread further. When either of these results has become apparent, controversy on the subject flags, and gradually dies away. The doctrine has taken its place, if not as a received opinion, as one of the admitted sects or divisions of opinion: those who hold it have generally inherited, not adopted it; and conversion from one of these doctrines to another, being now an exceptional fact, occupies little place in the thoughts of their professors. Instead of being, as at first, constantly on the alert either to defend themselves against the world, or to bring the world over to them, they have subsided into acquiescence, and neither listen, when they can help it, to arguments against their creed, nor trouble dissentients (if there be such) with arguments in its favour. From this time may usually be dated the decline in the living power of the doctrine.

We often hear the teachers of all creeds lamenting the difficulty of keeping up in the minds of believers a lively apprehension of the truth which they nominally recognise, so that it may penetrate the feelings, and acquire a real mastery over the conduct. No such difficulty is complained of while the creed is still fighting for its existence: even the weaker combatants then know and feel what they are fighting for, and 
the difference between it and other doctrines; and in that period of every creed's existence, not a few persons may be found, who have realised its fundamental principles in all the forms of thought, have weighed and considered them in all their important bearings, and have experienced the full effect on the character which belief in that creed ought to produce in a mind thoroughly imbued with it. But when it has come to be an hereditary creed, and to be received passively, not actively - when the mind is no longer compelled, in the same degree as at first, to exercise its vital powers on the questions which its belief presents to it, there is a progressive tendency to forget all of the belief except the formularies, or to give it a dull and torpid assent, as if accepting it on trust dispensed with the necessity of realising it in consciousness, or testing it by personal experience, until it almost ceases to connect itself at all with the inner life of the human being. Then are seen the cases, so frequent in this age of the world as almost to form the majority, in which the creed remains as it were outside the mind, incrusting and petrifying it against all other influences addressed to the higher parts of our nature; manifesting its power by not suffering any fresh and living conviction to get in, but itself doing nothing for the mind or heart, except standing sentinel over them to keep them vacant.

To what an extent doctrines intrinsically fitted to make the deepest impression upon the mind may remain in it as dead beliefs, without being ever realised in the imagination, the feelings, or the understanding, is exemplified by the manner in which the majority of believers hold the doctrines of Christianity. By Christianity I here mean what is accounted such by all churches and sects-the maxims and precepts contained in the New Testament. These are considered sacred, and accepted as laws, by all professing Christians. Yet it is scarcely too much to say that not one Christian in a thousand guides or tests his individual conduct by reference to those laws. The standard to which he does refer it, is the custom of his nation, his class, or his religious profession. He has thus, on the one hand, a collection of ethical maxims, which he believes to have been vouchsafed to him by infallible wisdom as rules for his government; and on the other a set of every-day judgments and practices, which go a certain length with some of those maxims, not so great a length with others, stand in direct opposition to some, and are, on the whole, a compromise between the Christian creed and the interests and suggestions of worldly life. To the first of these standards he gives his homage; to the other his real allegiance. 
All Christians believe that the blessed are the poor and humble, and those who are ill-used by the world; that it is easier for a camel to pass through the eye of a needle than for a rich man to enter the kingdom of heaven; that they should judge not, lest they be judged; that they should swear not at all; that they should love their neighbour as themselves; that if one take their cloak, they should give him their coat also; that they should take no thought for the morrow; that if they would be perfect they should sell all that they have and give it to the poor. They are not insincere when they say that they believe these things. They do believe them, as people believe what they have always heard lauded and never discussed. But in the sense of that living belief which regulates conduct, they believe these doctrines just up to the point to which it is usual to act upon them. The doctrines in their integrity are serviceable to pelt adversaries with; and it is understood that they are to be put forward (when possible) as the reasons for whatever people do that they think laudable. But any one who reminded them that the maxims require an infinity of things which they never even think of doing, would gain nothing but to be classed among those very unpopular characters who affect to be better than other people. The doctrines have no hold on ordinary believers-are not a power in their minds. They have an habitual respect for the sound of them, but no feeling which spreads from the words to the things signified, and forces the mind to take them in, and make them conform to the formula. Whenever conduct is concerned, they look round for Mr. A and B to direct them how far to go in obeying Christ.

Now we may be well assured that the case was not thus, but far otherwise, with the early Christians. Had it been thus, Christianity never would have expanded from an obscure sect of the despised Hebrews into the religion of the Roman empire. When their enemies said, "See how these Christians love one another" (a remark not likely to be made by anybody now), they assuredly had a much livelier feeling of the meaning of their creed than they have ever had since. And to this cause, probably, it is chiefly owing that Christianity now makes so little progress in extending its domain, and after eighteen centuries is still nearly confined to Europeans and the descendants of Europeans. Even with the strictly religious, who are much in earnest about their doctrines, and attach a greater amount of meaning to many of them than people in general, it commonly happens that the part which is thus comparatively active in their minds is that which was made by Calvin, or Knox, or 
some such person much nearer in character to themselves. The sayings of Christ coexist passively in their minds, producing hardly any effect beyond what is caused by mere listening to words so amiable and bland. There are many reasons, doubtless, why doctrines which are the badge of a sect retain more of their vitality than those common to all recognised sects, and why more pains are taken by teachers to keep their meaning alive; but one reason certainly is, that the peculiar doctrines are more questioned, and have to be oftener defended against open gainsayers. Both teachers and learners go to sleep at their post, as soon as there is no enemy in the field.

The same thing holds true, generally speaking, of all traditional doctrines - those of prudence and knowledge of life, as well as of morals or religion. All languages and literatures are full of general observations on life, both as to what it is, and how to conduct oneself in it; observations which everybody knows, which everybody repeats, or hears with acquiescence, which are received as truisms, yet of which most people first truly learn the meaning when experience, generally of a painful kind, has made it a reality to them. How often, when smarting under some unforeseen misfortune or disappointment, does a person call to mind some proverb or common saying, familiar to him all his life, the meaning of which, if he had ever before felt it as he does now, would have saved him from the calamity. There are indeed reasons for this, other than the absence of discussion; there are many truths of which the full meaning cannot be realised until personal experience has brought it home. But much more of the meaning even of these would have been understood, and what was understood would have been far more deeply impressed on the mind, if the man had been accustomed to hear it argued pro and con by people who did understand it. The fatal tendency of mankind to leave off thinking about a thing when it is no longer doubtful, is the cause of half their errors. A contemporary author has well spoken of "the deep slumber of a decided opinion."

But what! (it may be asked) Is the absence of unanimity an indispensable condition of true knowledge? Is it necessary that some part of mankind should persist in error to enable any to realise the truth? Does a belief cease to be real and vital as soon as it is generally receivedand is a proposition never thoroughly understood and felt unless some doubt of it remains? As soon as mankind have unanimously accepted a truth, does the truth perish within them? The highest aim and best result of improved intelligence, it has hitherto been thought, is to unite man- 
kind more and more in the acknowledgment of all important truths; and does the intelligence only last as long as it has not achieved its object? Do the fruits of conquest perish by the very completeness of the victory?

I affirm no such thing. As mankind improve, the number of doctrines which are no longer disputed or doubted will be constantly on the increase: and the well-being of mankind may almost be measured by the number and gravity of the truths which have reached the point of being uncontested. The cessation, on one question after another, of serious controversy, is one of the necessary incidents of the consolidation of opinion; a consolidation as salutary in the case of true opinions, as it is dangerous and noxious when the opinions are erroneous. But though this gradual narrowing of the bounds of diversity of opinion is necessary in both senses of the term, being at once inevitable and indispensable, we are not therefore obliged to conclude that all its consequences must be beneficial. The loss of so important an aid to the intelligent and living apprehension of a truth, as is afforded by the necessity of explaining it to, or defending it against, opponents, though not sufficient to outweigh, is no trifling drawback from, the benefit of its universal recognition. Where this advantage can no longer be had, I confess I should like to see the teachers of mankind endeavouring to provide a substitute for it; some contrivance for making the difficulties of the question as present to the learner's consciousness, as if they were pressed upon him by a dissentient champion, eager for his conversion.

But instead of seeking contrivances for this purpose, they have lost those they formerly had. The Socratic dialectics, so magnificently exemplified in the dialogues of Plato, were a contrivance of this description. They were essentially a negative discussion of the great question of philosophy and life, directed with consummate skill to the purpose of convincing any one who had merely adopted the commonplaces of received opinion that he did not understand the subject—-that he as yet attached no definite meaning to the doctrines he professed; in order that, becoming aware of his ignorance, he might be put in the way to obtain a stable belief, resting on a clear apprehension both of the meaning of doctrines and of their evidence. The school disputations of the Middle Ages had a somewhat similar object. They were intended to make sure that the pupil understood his own opinion, and (by necessary correlation) the opinion opposed to it, and could enforce the grounds of the one and confute those of the other. These last-mentioned contests had indeed the incurable defect, that the premises appealed to were taken from au- 
thority, not from reason; and, as a discipline to the mind, they were in every respect inferior to the powerful dialectics which formed the intellects of the "Socratici viri"; but the modern mind owes far more to both than it is generally willing to admit, and the present modes of education contain nothing which in the smallest degree supplies the place either of the one or of the other. A person who derives all his instruction from teachers or books, even if he escape the besetting temptation of contenting himself with cram, is under no compulsion to hear both sides; accordingly it is far from a frequent accomplishment, even among thinkers, to know both sides; and the weakest part of what everybody says in defence of his opinion is what he intends as a reply to antagonists.

It is the fashion of the present time to disparage negative logicthat which points out weaknesses in theory or errors in practice, without establishing positive truths. Such negative criticism would indeed be poor enough as an ultimate result; but as a means to attaining any positive knowledge or conviction worthy the name, it cannot be valued too highly; and until people are again systematically trained to it, there will be few great thinkers, and a low general average of intellect, in any but the mathematical and physical departments of speculation. On any other subject no one's opinions deserve the name of knowledge, except so far as he has either had forced upon him by others, or gone through of himself, the same mental process which would have been required of him in carrying on an active controversy with opponents. That, therefore, which when absent, it is so indispensable, but so difficult, to create, how worse than absurd it is to forego, when spontaneously offering itself! If there are any persons who contest a received opinion, or who will do so if law or opinion will let them, let us thank them for it, open our minds to listen to them, and rejoice that there is some one to do for us what we otherwise ought, if we have any regard for either the certainty or the vitality of our convictions, to do with much greater labour for ourselves.

It still remains to speak of one of the principal causes which make diversity of opinion advantageous, and will continue to do so until mankind shall have entered a stage of intellectual advancement which at present seems at an incalculable distance. We have hitherto considered only two possibilities: that the received opinion may be false, and some other opinion, consequently, true; or that, the received opinion being true, a conflict with the opposite error is essential to a clear apprehension and deep feeling of its truth. But there is a commoner case than 


\section{4/John Stuart Mill}

either of these; when the conflicting doctrines, instead of being one true and the other false, share the truth between them; and the nonconforming opinion is needed to supply the remainder of the truth, of which the received doctrine embodies only a part. Popular opinions, on subjects not palpable to sense, are often true, but seldom or never the whole truth. They are a part of the truth; sometimes a greater, sometimes a smaller part, but exaggerated, distorted, and disjointed from the truths by which they ought to be accompanied and limited. Heretical opinions, on the other hand, are generally some of these suppressed and neglected truths, bursting the bonds which kept them down, and either seeking reconciliation with the truth contained in the common opinion, or fronting it as enemies, and setting themselves up, with similar exclusiveness, as the whole truth. The latter case is hitherto the most frequent, as, in the human mind, one-sidedness has always been the rule, and many-sidedness the exception. Hence, even in revolutions of opinion, one part of the truth usually sets while another rises. Even progress, which ought to superadd, for the most part only substitutes, one partial and incomplete truth for another; improvement consisting chiefly in this, that the new fragment of truth is more wanted, more adapted to the needs of the time, than that which it displaces. Such being the partial character of prevailing opinions, even when resting on a true foundation, every opinion which embodies somewhat of the portion of truth which the common opinion omits, ought to be considered precious, with whatever amount of error and confusion that truth may be blended. No sober judge of human affairs will feel bound to be indignant because those who force on our notice truths which we should otherwise have overlooked, overlook some of those which we see. Rather, he will think that so long as popular truth is one-sided, it is more desirable than otherwise that unpopular truth should have one-sided assertors too; such being usually the most energetic, and the most likely to compel reluctant attention to the fragment of wisdom which they proclaim as if it were the whole.

Thus, in the eighteenth century, when nearly all the instructed, and all those of the uninstructed who were led by them, were lost in admiration of what is called civilisation, and of the marvels of modern science, literature, and philosophy, and while greatly overrating the amount of unlikeness between the men of modern and those of ancient times, indulged the belief that the whole of the difference was in their own favour; with what a salutary shock did the paradoxes of Rousseau explode like bombshells in the midst, dislocating the compact mass of one-sided opin- 
ion, and forcing its elements to recombine in a better form and with additional ingredients. Not that the current opinions were on the whole farther from the truth than Rousseau's were; on the contrary, they were nearer to it; they contained more of positive truth, and very much less of error. Nevertheless there lay in Rousseau's doctrine, and has floated down the stream of opinion along with it, a considerable amount of exactly those truths which the popular opinion wanted; and these are the deposit which was left behind when the flood subsided. The superior worth of simplicity of life, the enervating and demoralising effect of the trammels and hypocrisies of artificial society, are ideas which have never been entirely absent from cultivated minds since Rousseau wrote; and they will in time produce their due effect, though at present needing to be asserted as much as ever, and to be asserted by deeds, for words, on this subject, have nearly exhausted their power.

In politics, again, it is almost a commonplace, that a party of order or stability, and a party of progress or reform, are both necessary elements of a healthy state of political life; until the one or the other shall have so enlarged its mental grasp as to be a party equally of order and of progress, knowing and distinguishing what is fit to be preserved from what ought to be swept away. Each of these modes of thinking derives its utility from the deficiencies of the other; but it is in a great measure the opposition of the other that keeps each within the limits of reason and sanity. Unless opinions favourable to democracy and to aristocracy, to property and to equality, to cooperation and to competition, to luxury and to abstinence, to sociality and individuality, to liberty and discipline, and all the other standing antagonisms of practical life, are expressed with equal freedom, and enforced and defended with equal talent and energy, there is no chance of both elements obtaining their due; one scale is sure to go up, and the other down. Truth, in the great practical concerns of life, is so much a question of the reconciling and combining of opposites, that very few have minds sufficiently capacious and impartial to make the adjustment with an approach to correctness, and it has to be made by the rough process of a struggle between combatants fighting under hostile banners. On any of the great open questions just enumerated, if either of the two opinions has a better claim than the other, not merely to be tolerated, but to be encouraged and countenanced, it is the one which happens at the particular time and place to be in a minority. That is the opinion which, for the time being, represents the neglected interests, the side of human well-being which is 
in danger of obtaining less than its share. I am aware that there is not, in this country, any intolerance of differences of opinion on most of these topics. They are adduced to show, by admitted and multiplied examples, the universality of the fact, that only through diversity of opinion is there, in the existing state of human intellect, a chance of fair play to all sides of the truth. When there are persons to be found who form an exception to the apparent unanimity of the world on any subject, even if the world is in the right, it is always probable that dissentients have something worth hearing to say for themselves, and that truth would lose something by their silence.

It may be objected, "But some received principles, especially on the highest and most vital subjects, are more than half-truths. The Christian morality, for instance, is the whole truth on that subject, and if any one teaches a morality which varies from it, he is wholly in error." As this is of all cases the most important in practice, none can be fitter to test the general maxim. But before pronouncing what Christian morality is or is not, it would be desirable to decide what is meant by Christian morality. If it means the morality of the New Testament, I wonder that any one who derives his knowledge of this from the book itself, can suppose that it was announced, or intended, as a complete doctrine of morals. The Gospel always refers to a pre-existing morality, and confines its precepts to the particulars in which that morality was to be corrected, or superseded by a wider and higher; expressing itself, moreover, in terms most general, often impossible to be interpreted literally, and possessing rather the impressiveness of poetry or eloquence than the precision of legislation. To extract from it a body of ethical doctrine, has never been possible without eking it out from the Old Testament, that is, from a system elaborate indeed, but in many respects barbarous, and intended only for a barbarous people. St. Paul, a declared enemy to this Judaical mode of interpreting the doctrine and filling up the scheme of his Master, equally assumes a preexisting morality, namely that of the Greeks and Romans; and his advice to Christians is in a great measure a system of accommodation to that; even to the extent of giving an apparent sanction to slavery. What is called Christian, but should rather be termed theological, morality, was not the work of Christ or the Apostles, but is of much later origin, having been gradually built up by the Catholic church of the first five centuries, and though not implicitly adopted by moderns and Protestants, has been much less modified by them than might have been expected. For the most part, indeed, they have con- 
tented themselves with cutting off the additions which had been made to it in the Middle Ages, each sect supplying the place by fresh additions, adapted to its own character and tendencies.

That mankind owe a great debt to this morality, and to its early teachers, I should be the last person to deny; but I do not scruple to say of it that it is, in many important points, incomplete and one-sided, and that unless ideas and feelings, not sanctioned by it, had contributed to the formation of European life and character, human affairs would have been in a worse condition than they now are. Christian morality (so called) has all the characters of a reaction; it is, in great part, a protest against Paganism. Its ideal is negative rather than positive; passive rather than active; Innocence rather than Nobleness; Abstinence from Evil, rather than energetic Pursuit of Good; in its precepts (as has been well said) "thou shalt not" predominates unduly over "thou shalt." In its horror of sensuality, it made an idol of asceticism, which has been gradually compromised away into one of legality. It holds out the hope of heaven and the threat of hell, as the appointed and appropriate motives to a virtuous life: in this falling far below the best of the ancients, and doing what lies in it to give to human morality an essentially selfish character, by disconnecting each man's feelings of duty from the interests of his fellow creatures, except so far as a self-interested inducement is offered to him for consulting them. It is essentially a doctrine of passive obedience; it inculcates submission to all authorities found established; who indeed are not to be actively obeyed when they command what religion forbids, but who are not to be resisted, far less rebelled against, for any amount of wrong to ourselves. And while, in the morality of the best Pagan nations, duty to the State holds even a disproportionate place, infringing on the just liberty of the individual; in purely Christian ethics, that grand department of duty is scarcely noticed or acknowledged. It is in the Koran, not the New Testament, that we read the maxim - "A ruler who appoints any man to an office, when there is in his dominions another man better qualified for it, sins against God and against the State." What little recognition the idea of obligation to the public obtains in modern morality is derived from Greek and Roman sources, not from Christian; as, even in the morality of private life, whatever exists of magnanimity, highmindedness, personal dignity, even the sense of honour, is derived from the purely human, not the religious part of our education, and never could have grown out of a standard of ethics in which the only worth, professedly recognised, is that of obedi- 
ence.

I am as far as any one from pretending that these defects are necessarily inherent in the Christian ethics in every manner in which it can be conceived, or that the many requisites of a complete moral doctrine which it does not contain do not admit of being reconciled with it. Far less would I insinuate this of the doctrines and precepts of Christ himself. I believe that the sayings of Christ are all that I can see any evidence of their having been intended to be; that they are irreconcilable with nothing which a comprehensive morality requires; that everything which is excellent in ethics may be brought within them, with no greater violence to their language than has been done to it by all who have attempted to deduce from them any practical system of conduct whatever. But it is quite consistent with this to believe that they contain, and were meant to contain, only a part of the truth; that many essential elements of the highest morality are among the things which are not provided for, nor intended to be provided for, in the recorded deliverances of the Founder of Christianity, and which have been entirely thrown aside in the system of ethics erected on the basis of those deliverances by the Christian Church. And this being so, I think it a great error to persist in attempting to find in the Christian doctrine that complete rule for our guidance which its author intended it to sanction and enforce, but only partially to provide. I believe, too, that this narrow theory is becoming a grave practical evil, detracting greatly from the moral training and instruction which so many well-meaning persons are now at length exerting themselves to promote. I much fear that by attempting to form the mind and feelings on an exclusively religious type, and discarding those secular standards (as for want of a better name they may be called) which heretofore coexisted with and supplemented the Christian ethics, receiving some of its spirit, and infusing into it some of theirs, there will result, and is even now resulting, a low, abject, servile type of character, which, submit itself as it may to what it deems the Supreme Will, is incapable of rising to or sympathising in the conception of Supreme Goodness. I believe that other ethics than any which can be evolved from exclusively Christian sources, must exist side by side with Christian ethics to produce the moral regeneration of mankind; and that the Christian system is no exception to the rule, that in an imperfect state of the human mind the interests of truth require a diversity of opinions.

It is not necessary that in ceasing to ignore the moral truths not 
contained in Christianity men should ignore any of those which it does contain. Such prejudice, or oversight, when it occurs, is altogether an evil; but it is one from which we cannot hope to be always exempt, and must be regarded as the price paid for an inestimable good. The exclusive pretension made by a part of the truth to be the whole, must and ought to be protested against; and if a reactionary impulse should make the protestors unjust in their turn, this one-sidedness, like the other, may be lamented, but must be tolerated. If Christians would teach infidels to be just to Christianity, they should themselves be just to infidelity. It can do truth no service to blink the fact, known to all who have the most ordinary acquaintance with literary history, that a large portion of the noblest and most valuable moral teaching has been the work, not only of men who did not know, but of men who knew and rejected, the Christian faith.

I do not pretend that the most unlimited use of the freedom of enunciating all possible opinions would put an end to the evils of religious or philosophical sectarianism. Every truth which men of narrow capacity are in earnest about, is sure to be asserted, inculcated, and in many ways even acted on, as if no other truth existed in the world, or at all events none that could limit or qualify the first. I acknowledge that the tendency of all opinions to become sectarian is not cured by the freest discussion, but is often heightened and exacerbated thereby; the truth which ought to have been, but was not, seen, being rejected all the more violently because proclaimed by persons regarded as opponents. But it is not on the impassioned partisan, it is on the calmer and more disinterested bystander, that this collision of opinions works its salutary effect. Not the violent conflict between parts of the truth, but the quiet suppression of half of it, is the formidable evil; there is always hope when people are forced to listen to both sides; it is when they attend only to one that errors harden into prejudices, and truth itself ceases to have the effect of truth, by being exaggerated into falsehood. And since there are few mental attributes more rare than that judicial faculty which can sit in intelligent judgment between two sides of a question, of which only one is represented by an advocate before it, truth has no chance but in proportion as every side of it, every opinion which embodies any fraction of the truth, not only finds advocates, but is so advocated as to be listened to.

We have now recognised the necessity to the mental well-being of mankind (on which all their other well-being depends) of freedom of 
opinion, and freedom of the expression of opinion, on four distinct grounds; which we will now briefly recapitulate.

First, if any opinion is compelled to silence, that opinion may, for aught we can certainly know, be true. To deny this is to assume our own infallibility.

Secondly, though the silenced opinion be an error, it may, and very commonly does, contain a portion of truth; and since the general or prevailing opinion on any subject is rarely or never the whole truth, it is only by the collision of adverse opinions that the remainder of the truth has any chance of being supplied.

Thirdly, even if the received opinion be not only true, but the whole truth; unless it is suffered to be, and actually is, vigorously and earnestly contested, it will, by most of those who receive it, be held in the manner of a prejudice, with little comprehension or feeling of its rational grounds. And not only this, but, fourthly, the meaning of the doctrine itself will be in danger of being lost, or enfeebled, and deprived of its vital effect on the character and conduct: the dogma becoming a mere formal profession, inefficacious for good, but cumbering the ground, and preventing the growth of any real and heartfelt conviction, from reason or personal experience.

Before quitting the subject of freedom of opinion, it is fit to take some notice of those who say that the free expression of all opinions should be permitted, on condition that the manner be temperate, and do not pass the bounds of fair discussion. Much might be said on the impossibility of fixing where these supposed bounds are to be placed; for if the test be offence to those whose opinions are attacked, I think experience testifies that this offence is given whenever the attack is telling and powerful, and that every opponent who pushes them hard, and whom they find it difficult to answer, appears to them, if he shows any strong feeling on the subject, an intemperate opponent.

But this, though an important consideration in a practical point of view, merges in a more fundamental objection. Undoubtedly the manner of asserting an opinion, even though it be a true one, may be very objectionable, and may justly incur severe censure. But the principal offences of the kind are such as it is mostly impossible, unless by accidental selfbetrayal, to bring home to conviction. The gravest of them is, to argue sophistically, to suppress facts or arguments, to misstate the elements of the case, or misrepresent the opposite opinion. But all this, even to the most aggravated degree, is so continually done in perfect good faith, by 
persons who are not considered, and in many other respects may not deserve to be considered, ignorant or incompetent, that it is rarely possible, on adequate grounds, conscientiously to stamp the misrepresentation as morally culpable; and still less could law presume to interfere with this kind of controversial misconduct. With regard to what is commonly meant by intemperate discussion, namely invective, sarcasm, personality, and the like, the denunciation of these weapons would deserve more sympathy if it were ever proposed to interdict them equally to both sides; but it is only desired to restrain the employment of them against the prevailing opinion: against the unprevailing they may not only be used without general disapproval, but will be likely to obtain for him who uses them the praise of honest zeal and righteous indignation. Yet whatever mischief arises from their use is greatest when they are employed against the comparatively defenceless; and whatever unfair advantage can be derived by any opinion from this mode of asserting it, accrues almost exclusively to received opinions. The worst offence of this kind which can be committed by a polemic is to stigmatise those who hold the contrary opinion as bad and immoral men. To calumny of this sort, those who hold any unpopular opinion are peculiarly exposed, because they are in general few and uninfluential, and nobody but themselves feels much interested in seeing justice done them; but this weapon is, from the nature of the case, denied to those who attack a prevailing opinion: they can neither use it with safety to themselves, nor, if they could, would it do anything but recoil on their own cause. In general, opinions contrary to those commonly received can only obtain a hearing by studied moderation of language, and the most cautious avoidance of unnecessary offence, from which they hardly ever deviate even in a slight degree without losing ground: while unmeasured vituperation employed on the side of the prevailing opinion really does deter people from professing contrary opinions, and from listening to those who profess them.

For the interest, therefore, of truth and justice, it is far more important to restrain this employment of vituperative language than the other; and, for example, if it were necessary to choose, there would be much more need to discourage offensive attacks on infidelity than on religion. It is, however, obvious that law and authority have no business with restraining either, while opinion ought, in every instance, to determine its verdict by the circumstances of the individual case; condemning every one, on whichever side of the argument he places himself, in whose mode of advocacy either want of candour, or malignity, bigotry, or in- 


\section{2/John Stuart Mill}

tolerance of feeling manifest themselves; but not inferring these vices from the side which a person takes, though it be the contrary side of the question to our own; and giving merited honour to every one, whatever opinion he may hold, who has calmness to see and honesty to state what his opponents and their opinions really are, exaggerating nothing to their discredit, keeping nothing back which tells, or can be supposed to tell, in their favour. This is the real morality of public discussion: and if often violated, I am happy to think that there are many controversialists who to a great extent observe it, and a still greater number who conscientiously strive towards it.

\section{Chapter 3. Of Individuality, as one of the Elements of Well- being.}

Such being the reasons which make it imperative that human beings should be free to form opinions, and to express their opinions without reserve; and such the baneful consequences to the intellectual, and through that to the moral nature of man, unless this liberty is either conceded, or asserted in spite of prohibition; let us next examine whether the same reasons do not require that men should be free to act upon their opinions- to carry these out in their lives, without hindrance, either physical or moral, from their fellow-men, so long as it is at their own risk and peril.

This last proviso is of course indispensable. No one pretends that actions should be as free as opinions. On the contrary, even opinions lose their immunity when the circumstances in which they are expressed are such as to constitute their expression a positive instigation to some mischievous act. An opinion that corn-dealers are starvers of the poor, or that private property is robbery, ought to be unmolested when simply circulated through the press, but may justly incur punishment when delivered orally to an excited mob assembled before the house of a corndealer, or when handed about among the same mob in the form of a placard. Acts, of whatever kind, which, without justifiable cause, do harm to others, may be, and in the more important cases absolutely require to be, controlled by the unfavourable sentiments, and, when needful, by the active interference of mankind. The liberty of the individual must be thus far limited; he must not make himself a nuisance to other people. But if he refrains from molesting others in what concerns them, 
and merely acts according to his own inclination and judgment in things which concern himself, the same reasons which show that opinion should be free, prove also that he should be allowed, without molestation, to carry his opinions into practice at his own cost. That mankind are not infallible; that their truths, for the most part, are only half-truths; that unity of opinion, unless resulting from the fullest and freest comparison of opposite opinions, is not desirable, and diversity not an evil, but a good, until mankind are much more capable than at present of recognising all sides of the truth, are principles applicable to men's modes of action, not less than to their opinions. As it is useful that while mankind are imperfect there should be different opinions, so it is that there should be different experiments of living; that free scope should be given to varieties of character, short of injury to others; and that the worth of different modes of life should be proved practically, when any one thinks fit to try them. It is desirable, in short, that in things which do not primarily concern others, individuality should assert itself. Where, not the person's own character, but the traditions or customs of other people are the rule of conduct, there is wanting one of the principal ingredients of human happiness, and quite the chief ingredient of individual and social progress.

In maintaining this principle, the greatest difficulty to be encountered does not lie in the appreciation of means towards an acknowledged end, but in the indifference of persons in general to the end itself. If it were felt that the free development of individuality is one of the leading essentials of well-being; that it is not only a co-ordinate element with all that is designated by the terms civilisation, instruction, education, culture, but is itself a necessary part and condition of all those things; there would be no danger that liberty should be undervalued, and the adjustment of the boundaries between it and social control would present no extraordinary difficulty. But the evil is, that individual spontaneity is hardly recognised by the common modes of thinking as having any intrinsic worth, or deserving any regard on its own account. The majority, being satisfied with the ways of mankind as they now are (for it is they who make them what they are), cannot comprehend why those ways should not be good enough for everybody; and what is more, spontaneity forms no part of the ideal of the majority of moral and social reformers, but is rather looked on with jealousy, as a troublesome and perhaps rebellious obstruction to the general acceptance of what these reformers, in their own judgment, think would be best for mankind. Few persons, out of Germany, even comprehend the meaning of the doctrine 


\section{4/John Stuart Mill}

which Wilhelm von Humboldt, so eminent both as a savant and as a politician, made the text of a treatise- that "the end of man, or that which is prescribed by the eternal or immutable dictates of reason, and not suggested by vague and transient desires, is the highest and most harmonious development of his powers to a complete and consistent whole"; that, therefore, the object "towards which every human being must ceaselessly direct his efforts, and on which especially those who design to influence their fellow-men must ever keep their eyes, is the individuality of power and development"; that for this there are two requisites, "freedom, and variety of situations"; and that from the union of these arise "individual vigour and manifold diversity," which combine themselves in "originality."

Little, however, as people are accustomed to a doctrine like that of Von Humboldt, and surprising as it may be to them to find so high a value attached to individuality, the question, one must nevertheless think, can only be one of degree. No one's idea of excellence in conduct is that people should do absolutely nothing but copy one another. No one would assert that people ought not to put into their mode of life, and into the conduct of their concerns, any impress whatever of their own judgment, or of their own individual character. On the other hand, it would be absurd to pretend that people ought to live as if nothing whatever had been known in the world before they came into it; as if experience had as yet done nothing towards showing that one mode of existence or of conduct, is preferable to another. Nobody denies that people should be so taught and trained in youth as to know and benefit by the ascertained results of human experience. But it is the privilege and proper condition of a human being, arrived at the maturity of his faculties, to use and interpret experience in his own way. It is for him to find out what part of recorded experience is properly applicable to his own circumstances and character. The traditions and customs of other people are, to a certain extent, evidence of what their experience has taught them; presumptive evidence, and as such, have a claim to his deference: but, in the first place, their experience may be too narrow; or they may not have interpreted it rightly. Secondly, their interpretation of experience may be correct, but unsuitable to him. Customs are made for customary circumstances and customary characters; and his circumstances or his character may be uncustomary. Thirdly, though the customs be both good as customs, and suitable to him, yet to conform to custom, merely as custom, does not educate or develop in him any of the qualities which are 
the distinctive endowment of a human being. The human faculties of perception, judgment, discriminative feeling, mental activity, and even moral preference, are exercised only in making a choice. He who does anything because it is the custom makes no choice. He gains no practice either in discerning or in desiring what is best. The mental and moral, like the muscular powers, are improved only by being used. The faculties are called into no exercise by doing a thing merely because others do it, no more than by believing a thing only because others believe it. If the grounds of an opinion are not conclusive to the person's own reason, his reason cannot be strengthened, but is likely to be weakened, by his adopting it: and if the inducements to an act are not such as are consentaneous to his own feelings and character (where affection, or the rights of others, are not concerned) it is so much done towards rendering his feelings and character inert and torpid, instead of active and energetic.

He who lets the world, or his own portion of it, choose his plan of life for him, has no need of any other faculty than the ape-like one of imitation. He who chooses his plan for himself, employs all his faculties. He must use observation to see, reasoning and judgment to foresee, activity to gather materials for decision, discrimination to decide, and when he has decided, firmness and self-control to hold to his deliberate decision. And these qualities he requires and exercises exactly in proportion as the part of his conduct which he determines according to his own judgment and feelings is a large one. It is possible that he might be guided in some good path, and kept out of harm's way, without any of these things. But what will be his comparative worth as a human being? It really is of importance, not only what men do, but also what manner of men they are that do it. Among the works of man, which human life is rightly employed in perfecting and beautifying, the first in importance surely is man himself. Supposing it were possible to get houses built, corn grown, battles fought, causes tried, and even churches erected and prayers said, by machinery—by automatons in human form-it would be a considerable loss to exchange for these automatons even the men and women who at present inhabit the more civilised parts of the world, and who assuredly are but starved specimens of what nature can and will produce. Human nature is not a machine to be built after a model, and set to do exactly the work prescribed for it, but a tree, which requires to grow and develop itself on all sides, according to the tendency of the inward forces which make it a living thing. 
It will probably be conceded that it is desirable people should exercise their understandings, and that an intelligent following of custom, or even occasionally an intelligent deviation from custom, is better than a blind and simply mechanical adhesion to it. To a certain extent it is admitted that our understanding should be our own: but there is not the same willingness to admit that our desires and impulses should be our own likewise; or that to possess impulses of our own, and of any strength, is anything but a peril and a snare. Yet desires and impulses are as much a part of a perfect human being as beliefs and restraints: and strong impulses are only perilous when not properly balanced; when one set of aims and inclinations is developed into strength, while others, which ought to co-exist with them, remain weak and inactive. It is not because men's desires are strong that they act ill; it is because their consciences are weak. There is no natural connection between strong impulses and a weak conscience. The natural connection is the other way. To say that one person's desires and feelings are stronger and more various than those of another, is merely to say that he has more of the raw material of human nature, and is therefore capable, perhaps of more evil, but certainly of more good. Strong impulses are but another name for energy. Energy may be turned to bad uses; but more good may always be made of an energetic nature, than of an indolent and impassive one. Those who have most natural feeling are always those whose cultivated feelings may be made the strongest. The same strong susceptibilities which make the personal impulses vivid and powerful, are also the source from whence are generated the most passionate love of virtue, and the sternest self-control. It is through the cultivation of these that society both does its duty and protects its interests: not by rejecting the stuff of which heroes are made, because it knows not how to make them. A person whose desires and impulses are his own-are the expression of his own nature, as it has been developed and modified by his own culture-is said to have a character. One whose desires and impulses are not his own, has no character, no more than a steam-engine has a character. If, in addition to being his own, his impulses are strong, and are under the government of a strong will, he has an energetic character. Whoever thinks that individuality of desires and impulses should not be encouraged to unfold itself, must maintain that society has no need of strong natures-is not the better for containing many persons who have much character-and that a high general average of energy is not desirable.

In some early states of society, these forces might be, and were, too 
much ahead of the power which society then possessed of disciplining and controlling them. There has been a time when the element of spontaneity and individuality was in excess, and the social principle had a hard struggle with it. The difficulty then was to induce men of strong bodies or minds to pay obedience to any rules which required them to control their impulses. To overcome this difficulty, law and discipline, like the Popes struggling against the Emperors, asserted a power over the whole man, claiming to control all his life in order to control his character-which society had not found any other sufficient means of binding. But society has now fairly got the better of individuality; and the danger which threatens human nature is not the excess, but the deficiency, of personal impulses and preferences. Things are vastly changed since the passions of those who were strong by station or by personal endowment were in a state of habitual rebellion against laws and ordinances, and required to be rigorously chained up to enable the persons within their reach to enjoy any particle of security. In our times, from the highest class of society down to the lowest, every one lives as under the eye of a hostile and dreaded censorship. Not only in what concerns others, but in what concerns only themselves, the individual or the family do not ask themselves-what do I prefer? or, what would suit my character and disposition? or, what would allow the best and highest in me to have fair play, and enable it to grow and thrive? They ask themselves, what is suitable to my position? what is usually done by persons of my station and pecuniary circumstances? or (worse still) what is usually done by persons of a station and circumstances superior to mine? I do not mean that they choose what is customary in preference to what suits their own inclination. It does not occur to them to have any inclination, except for what is customary. Thus the mind itself is bowed to the yoke: even in what people do for pleasure, conformity is the first thing thought of; they like in crowds; they exercise choice only among things commonly done: peculiarity of taste, eccentricity of conduct, are shunned equally with crimes: until by dint of not following their own nature they have no nature to follow: their human capacities are withered and starved: they become incapable of any strong wishes or native pleasures, and are generally without either opinions or feelings of home growth, or properly their own. Now is this, or is it not, the desirable condition of human nature?

It is so, on the Calvinistic theory. According to that, the one great offence of man is self-will. All the good of which humanity is capable is 
comprised in obedience. You have no choice; thus you must do, and no otherwise: "whatever is not a duty, is a sin." Human nature being radically corrupt, there is no redemption for any one until human nature is killed within him. To one holding this theory of life, crushing out any of the human faculties, capacities, and susceptibilities, is no evil: man needs no capacity, but that of surrendering himself to the will of God: and if he uses any of his faculties for any other purpose but to do that supposed will more effectually, he is better without them. This is the theory of Calvinism; and it is held, in a mitigated form, by many who do not consider themselves Calvinists; the mitigation consisting in giving a less ascetic interpretation to the alleged will of God; asserting it to be his will that mankind should gratify some of their inclinations; of course not in the manner they themselves prefer, but in the way of obedience, that is, in a way prescribed to them by authority; and, therefore, by the necessary condition of the case, the same for all.

In some such insidious form there is at present a strong tendency to this narrow theory of life, and to the pinched and hidebound type of human character which it patronises. Many persons, no doubt, sincerely think that human beings thus cramped and dwarfed are as their Maker designed them to be; just as many have thought that trees are a much finer thing when clipped into pollards, or cut out into figures of animals, than as nature made them. But if it be any part of religion to believe that man was made by a good Being, it is more consistent with that faith to believe that this Being gave all human faculties that they might be cultivated and unfolded, not rooted out and consumed, and that he takes delight in every nearer approach made by his creatures to the ideal conception embodied in them, every increase in any of their capabilities of comprehension, of action, or of enjoyment. There is a different type of human excellence from the Calvinistic: a conception of humanity as having its nature bestowed on it for other purposes than merely to be abnegated. "Pagan self-assertion" is one of the elements of human worth, as well as "Christian self-denial." There is a Greek ideal of self-development, which the Platonic and Christian ideal of self-government blends with, but does not supersede. It may be better to be a John Knox than an Alcibiades, but it is better to be a Pericles than either; nor would a Pericles, if we had one in these days, be without anything good which belonged to John Knox.

It is not by wearing down into uniformity all that is individual in themselves, but by cultivating it, and calling it forth, within the limits 
imposed by the rights and interests of others, that human beings become a noble and beautiful object of contemplation; and as the works partake the character of those who do them, by the same process human life also becomes rich, diversified, and animating, furnishing more abundant aliment to high thoughts and elevating feelings, and strengthening the tie which binds every individual to the race, by making the race infinitely better worth belonging to. In proportion to the development of his individuality, each person becomes more valuable to himself, and is therefore capable of being more valuable to others. There is a greater fulness of life about his own existence, and when there is more life in the units there is more in the mass which is composed of them. As much compression as is necessary to prevent the stronger specimens of human nature from encroaching on the rights of others cannot be dispensed with; but for this there is ample compensation even in the point of view of human development. The means of development which the individual loses by being prevented from gratifying his inclinations to the injury of others, are chiefly obtained at the expense of the development of other people. And even to himself there is a full equivalent in the better development of the social part of his nature, rendered possible by the restraint put upon the selfish part. To be held to rigid rules of justice for the sake of others, develops the feelings and capacities which have the good of others for their object. But to be restrained in things not affecting their good, by their mere displeasure, develops nothing valuable, except such force of character as may unfold itself in resisting the restraint. If acquiesced in, it dulls and blunts the whole nature. To give any fair play to the nature of each, it is essential that different persons should be allowed to lead different lives. In proportion as this latitude has been exercised in any age, has that age been noteworthy to posterity. Even despotism does not produce its worst effects, so long as individuality exists under it; and whatever crushes individuality is despotism, by whatever name it may be called, and whether it professes to be enforcing the will of God or the injunctions of men.

Having said that the individuality is the same thing with development, and that it is only the cultivation of individuality which produces, or can produce, well-developed human beings, I might here close the argument: for what more or better can be said of any condition of human affairs than that it brings human beings themselves nearer to the best thing they can be? or what worse can be said of any obstruction to good than that it prevents this? Doubtless, however, these considerations 


\section{0/John Stuart Mill}

will not suffice to convince those who most need convincing; and it is necessary further to show, that these developed human beings are of some use to the undeveloped - to point out to those who do not desire liberty, and would not avail themselves of it, that they may be in some intelligible manner rewarded for allowing other people to make use of it without hindrance.

In the first place, then, I would suggest that they might possibly learn something from them. It will not be denied by anybody, that originality is a valuable element in human affairs. There is always need of persons not only to discover new truths, and point out when what were once truths are true no longer, but also to commence new practices, and set the example of more enlightened conduct, and better taste and sense in human life. This cannot well be gainsaid by anybody who does not believe that the world has already attained perfection in all its ways and practices. It is true that this benefit is not capable of being rendered by everybody alike: there are but few persons, in comparison with the whole of mankind, whose experiments, if adopted by others, would be likely to be any improvement on established practice. But these few are the salt of the earth; without them, human life would become a stagnant pool. Not only is it they who introduce good things which did not before exist; it is they who keep the life in those which already exist. If there were nothing new to be done, would human intellect cease to be necessary? Would it be a reason why those who do the old things should forget why they are done, and do them like cattle, not like human beings? There is only too great a tendency in the best beliefs and practices to degenerate into the mechanical; and unless there were a succession of persons whose everrecurring originality prevents the grounds of those beliefs and practices from becoming merely traditional, such dead matter would not resist the smallest shock from anything really alive, and there would be no reason why civilisation should not die out, as in the Byzantine Empire. Persons of genius, it is true, are, and are always likely to be, a small minority; but in order to have them, it is necessary to preserve the soil in which they grow. Genius can only breathe freely in an atmosphere of freedom. Persons of genius are, ex vi termini, more individual than any other people-less capable, consequently, of fitting themselves, without hurtful compression, into any of the small number of moulds which society provides in order to save its members the trouble of forming their own character. If from timidity they consent to be forced into one of these moulds, and to let all that part of themselves which cannot 
expand under the pressure remain unexpanded, society will be little the better for their genius. If they are of a strong character, and break their fetters, they become a mark for the society which has not succeeded in reducing them to commonplace, to point out with solemn warning as "wild," "erratic," and the like; much as if one should complain of the Niagara river for not flowing smoothly between its banks like a Dutch canal.

I insist thus emphatically on the importance of genius, and the necessity of allowing it to unfold itself freely both in thought and in practice, being well aware that no one will deny the position in theory, but knowing also that almost every one, in reality, is totally indifferent to it. People think genius a fine thing if it enables a man to write an exciting poem, or paint a picture. But in its true sense, that of originality in thought and action, though no one says that it is not a thing to be admired, nearly all, at heart, think that they can do very well without it. Unhappily this is too natural to be wondered at. Originality is the one thing which unoriginal minds cannot feel the use of. They cannot see what it is to do for them: how should they? If they could see what it would do for them, it would not be originality. The first service which originality has to render them, is that of opening their eyes: which being once fully done, they would have a chance of being themselves original. Meanwhile, recollecting that nothing was ever yet done which some one was not the first to do, and that all good things which exist are the fruits of originality, let them modest enough to believe that there is something still left for it to accomplish, and assure themselves that they are more in need of originality, the less they are conscious of the want.

In sober truth, whatever homage may be professed, or even paid, to real or supposed mental superiority, the general tendency of things throughout the world is to render mediocrity the ascendant power among mankind. In ancient history, in the Middle Ages, and in a diminishing degree through the long transition from feudality to the present time, the individual was a power in himself; and if he had either great talents or a high social position, he was a considerable power. At present individuals are lost in the crowd. In politics it is almost a triviality to say that public opinion now rules the world. The only power deserving the name is that of masses, and of governments while they make themselves the organ of the tendencies and instincts of masses. This is as true in the moral and social of private life as in public transactions. Those whose opinions go by the name of public opinion are not always the same sort 
of public: in America they are the whole white population; in England, chiefly the middle class. But they are always a mass, that is to say, collective mediocrity. And what is a still greater novelty, the mass do not now take their opinions from dignitaries in Church or State, from ostensible leaders, or from books. Their thinking is done for them by men much like themselves, addressing them or speaking in their name, on the spur of the moment, through the newspapers.

I am not complaining of all this. I do not assert that anything better is compatible, as a general rule, with the present low state of the human mind. But that does not hinder the government of mediocrity from being mediocre government. No government by a democracy or a numerous aristocracy, either in its political acts or in the opinions, qualities, and tone of mind which it fosters, ever did or could rise above mediocrity, except in so far as the sovereign Many have let themselves be guided (which in their best times they always have done) by the counsels and influence of a more highly gifted and instructed One or Few. The initiation of all wise or noble things comes and must come from individuals; generally at first from some one individual. The honour and glory of the average man is that he is capable of following that initiative; that he can respond internally to wise and noble things, and be led to them with his eyes open. I am not countenancing the sort of "hero-worship" which applauds the strong man of genius for forcibly seizing on the government of the world and making it do his bidding in spite of itself. All he can claim is, freedom to point out the way. The power of compelling others into it is not only inconsistent with the freedom and development of all the rest, but corrupting to the strong man himself. It does seem, however, that when the opinions of masses of merely average men are everywhere become or becoming the dominant power, the counterpoise and corrective to that tendency would be the more and more pronounced individuality of those who stand on the higher eminences of thought. It is in these circumstances most especially, that exceptional individuals, instead of being deterred, should be encouraged in acting differently from the mass. In other times there was no advantage in their doing so, unless they acted not only differently but better. In this age, the mere example of non-conformity, the mere refusal to bend the knee to custom, is itself a service. Precisely because the tyranny of opinion is such as to make eccentricity a reproach, it is desirable, in order to break through that tyranny, that people should be eccentric. Eccentricity has always abounded when and where strength of character has abounded; and the 
amount of eccentricity in a society has generally been proportional to the amount of genius, mental vigour, and moral courage it contained. That so few now dare to be eccentric marks the chief danger of the time.

I have said that it is important to give the freest scope possible to uncustomary things, in order that it may in time appear which of these are fit to be converted into customs. But independence of action, and disregard of custom, are not solely deserving of encouragement for the chance they afford that better modes action, and customs more worthy of general adoption, may be struck out; nor is it only persons of decided mental superiority who have a just claim to carry on their lives in their own way. There is no reason that all human existence should be constructed on some one or some small number of patterns. If a person possesses any tolerable amount of common sense and experience, his own mode of laying out his existence is the best, not because it is the best in itself, but because it is his own mode. Human beings are not like sheep; and even sheep are not undistinguishably alike. A man cannot get a coat or a pair of boots to fit him unless they are either made to his measure, or he has a whole warehouseful to choose from: and is it easier to fit him with a life than with a coat, or are human beings more like one another in their whole physical and spiritual conformation than in the shape of their feet? If it were only that people have diversities of taste, that is reason enough for not attempting to shape them all after one model.

But different persons also require different conditions for their spiritual development; and can no more exist healthily in the same moral, than all the variety of plants can in the same physical, atmosphere and climate. The same things which are helps to one person towards the cultivation of his higher nature are hindrances to another. The same mode of life is a healthy excitement to one, keeping all his faculties of action and enjoyment in their best order, while to another it is a distracting burthen, which suspends or crushes all internal life. Such are the differences among human beings in their sources of pleasure, their susceptibilities of pain, and the operation on them of different physical and moral agencies, that unless there is a corresponding diversity in their modes of life, they neither obtain their fair share of happiness, nor grow up to the mental, moral, and aesthetic stature of which their nature is capable. Why then should tolerance, as far as the public sentiment is concerned, extend only to tastes and modes of life which extort acquiescence by the multitude of their adherents? Nowhere (except in some 


\section{4/John Stuart Mill}

monastic institutions) is diversity of taste entirely unrecognised; a person may, without blame, either like or dislike rowing, or smoking, or music, or athletic exercises, or chess, or cards, or study, because both those who like each of these things, and those who dislike them, are too numerous to be put down. But the man, and still more the woman, who can be accused either of doing "What nobody does," or of not doing "what everybody does," is the subject of as much depreciatory remark as if he or she had committed some grave moral delinquency. Persons require to possess a title, or some other badge of rank, or of the consideration of people of rank, to be able to indulge somewhat in the luxury of doing as they like without detriment to their estimation. To indulge somewhat, I repeat: for whoever allow themselves much of that indulgence, incur the risk of something worse than disparaging speechesthey are in peril of a commission de lunatico, and of having their property taken from them and given to their relations. ${ }^{8}$

There is one characteristic of the present direction of public opinion peculiarly calculated to make it intolerant of any marked demonstration of individuality. The general average of mankind are not only moderate in intellect, but also moderate in inclinations: they have no tastes or wishes strong enough to incline them to do anything unusual, and they consequently do not understand those who have, and class all such with the wild and intemperate whom they are accustomed to look down upon. Now, in addition to this fact which is general, we have only to suppose that a strong movement has set in towards the improvement of morals, and it is evident what we have to expect. In these days such a movement has set in; much has actually been effected in the way of increased regularity of conduct and discouragement of excesses; and there is a philanthropic spirit abroad, for the exercise of which there is no more inviting field than the moral and prudential improvement of our fellow creatures. These tendencies of the times cause the public to be more disposed than at most former periods to prescribe general rules of conduct, and endeavour to make every one conform to the approved standard. And that standard, express or tacit, is to desire nothing strongly. Its ideal of character is to be without any marked character; to maim by compression, like a Chinese lady's foot, every part of human nature which stands out prominently, and tends to make the person markedly dissimilar in outline to commonplace humanity.

As is usually the case with ideals which exclude one-half of what is desirable, the present standard of approbation produces only an inferior 
imitation of the other half. Instead of great energies guided by vigorous reason, and strong feelings strongly controlled by a conscientious will, its result is weak feelings and weak energies, which therefore can be kept in outward conformity to rule without any strength either of will or of reason. Already energetic characters on any large scale are becoming merely traditional. There is now scarcely any outlet for energy in this country except business. The energy expended in this may still be regarded as considerable. What little is left from that employment is expended on some hobby; which may be a useful, even a philanthropic hobby, but is always some one thing, and generally a thing of small dimensions. The greatness of England is now all collective; individually small, we only appear capable of anything great by our habit of combining; and with this our moral and religious philanthropists are perfectly contented. But it was men of another stamp than this that made England what it has been; and men of another stamp will be needed to prevent its decline.

The despotism of custom is everywhere the standing hindrance to human advancement, being in unceasing antagonism to that disposition to aim at something better than customary, which is called, according to circumstances, the spirit of liberty, or that of progress or improvement. The spirit of improvement is not always a spirit of liberty, for it may aim at forcing improvements on an unwilling people; and the spirit of liberty, in so far as it resists such attempts, may ally itself locally and temporarily with the opponents of improvement; but the only unfailing and permanent source of improvement is liberty, since by it there are as many possible independent centres of improvement as there are individuals. The progressive principle, however, in either shape, whether as the love of liberty or of improvement, is antagonistic to the sway of Custom, involving at least emancipation from that yoke; and the contest between the two constitutes the chief interest of the history of mankind. The greater part of the world has, properly speaking, no history, because the despotism of Custom is complete. This is the case over the whole East. Custom is there, in all things, the final appeal; justice and right mean conformity to custom; the argument of custom no one, unless tyrant intoxicated with power, thinks of resisting. And we see the result. Those nations must once have had originality; they did not start out of the ground populous, lettered, and versed in many of the arts of life; they made themselves all this, and were then the greatest and most powerful nations of the world. What are they now? The subjects or 
dependents of tribes whose forefathers wandered in the forests when theirs had magnificent palaces and gorgeous temples, but over whom custom exercised only a divided rule with liberty and progress.

A people, it appears, may be progressive for a certain length of time, and then stop: when does it stop? When it ceases to possess individuality. If a similar change should befall the nations of Europe, it will not be in exactly the same shape: the despotism of custom with which these nations are threatened is not precisely stationariness. It proscribes singularity, but it does not preclude change, provided all change together. We have discarded the fixed costumes of our forefathers; every one must still dress like other people, but the fashion may change once or twice a year. We thus take care that when there is a change, it shall be for change's sake, and not from any idea of beauty or convenience; for the same idea of beauty or convenience would not strike all the world at the same moment, and be simultaneously thrown aside by all at another moment. But we are progressive as well as changeable: we continually make new inventions in mechanical things, and keep them until they are again superseded by better; we are eager for improvement in politics, in education, even in morals, though in this last our idea of improvement chiefly consists in persuading or forcing other people to be as good as ourselves. It is not progress that we object to; on the contrary, we flatter ourselves that we are the most progressive people who ever lived. It is individuality that we war against: we should think we had done wonders if we had made ourselves all alike; forgetting that the unlikeness of one person to another is generally the first thing which draws the attention of either to the imperfection of his own type, and the superiority of another, or the possibility, by combining the advantages of both, of producing something better than either. We have a warning example in China - a nation of much talent, and, in some respects, even wisdom, owing to the rare good fortune of having been provided at an early period with a particularly good set of customs, the work, in some measure, of men to whom even the most enlightened European must accord, under certain limitations, the title of sages and philosophers. They are remarkable, too, in the excellence of their apparatus for impressing, as far as possible, the best wisdom they possess upon every mind in the community, and securing that those who have appropriated most of it shall occupy the posts of honour and power. Surely the people who did this have discovered the secret of human progressiveness, and must have kept themselves steadily at the head of the movement of the world. On 
the contrary, they have become stationary-have remained so for thousands of years; and if they are ever to be farther improved, it must be by foreigners. They have succeeded beyond all hope in what English philanthropists are so industriously working at-in making a people all alike, all governing their thoughts and conduct by the same maxims and rules; and these are the fruits. The modern regime of public opinion is, in an unorganised form, what the Chinese educational and political systems are in an organised; and unless individuality shall be able successfully to assert itself against this yoke, Europe, notwithstanding its noble antecedents and its professed Christianity, will tend to become another China.

What is it that has hitherto preserved Europe from this lot? What has made the European family of nations an improving, instead of a stationary portion of mankind? Not any superior excellence in them, which, when it exists, exists as the effect not as the cause; but their remarkable diversity of character and culture. Individuals, classes, nations, have been extremely unlike one another: they have struck out a great variety of paths, each leading to something valuable; and although at every period those who travelled in different paths have been intolerant of one another, and each would have thought it an excellent thing if all the rest could have been compelled to travel his road, their attempts to thwart each other's development have rarely had any permanent success, and each has in time endured to receive the good which the others have offered. Europe is, in my judgment, wholly indebted to this plurality of paths for its progressive and many-sided development. But it already begins to possess this benefit in a considerably less degree. It is decidedly advancing towards the Chinese ideal of making all people alike. M. de Tocqueville, in his last important work, remarks how much more the Frenchmen of the present day resemble one another than did those even of the last generation. The same remark might be made of Englishmen in a far greater degree.

In a passage already quoted from Wilhelm von Humboldt, he points out two things as necessary conditions of human development, because necessary to render people unlike one another; namely, freedom, and variety of situations. The second of these two conditions is in this country every day diminishing. The circumstances which surround different classes and individuals, and shape their characters, are daily becoming more assimilated. Formerly different ranks, different neighbourhoods, different trades and professions, lived in what might be called different 
worlds; at present to a great degree in the same. Comparatively speaking, they now read the same things, listen to the same things, see the same things, go to the same places, have their hopes and fears directed to the same objects, have the same rights and liberties, and the same means of asserting them. Great as are the differences of position which remain, they are nothing to those which have ceased. And the assimilation is still proceeding. All the political changes of the age promote it, since they all tend to raise the low and to lower the high. Every extension of education promotes it, because education brings people under common influences, and gives them access to the general stock of facts and sentiments. Improvement in the means of communication promotes it, by bringing the inhabitants of distant places into personal contact, and keeping up a rapid flow of changes of residence between one place and another. The increase of commerce and manufactures promotes it, by diffusing more widely the advantages of easy circumstances, and opening all objects of ambition, even the highest, to general competition, whereby the desire of rising becomes no longer the character of a particular class, but of all classes. A more powerful agency than even all these, in bringing about a general similarity among mankind, is the complete establishment, in this and other free countries, of the ascendancy of public opinion in the State. As the various social eminences which enabled persons entrenched on them to disregard the opinion of the multitude gradually become levelled; as the very idea of resisting the will of the public, when it is positively known that they have a will, disappears more and more from the minds of practical politicians; there ceases to be any social support for nonconformity - any substantive power in society which, itself opposed to the ascendancy of numbers, is interested in taking under its protection opinions and tendencies at variance with those of the public.

The combination of all these causes forms so great a mass of influences hostile to Individuality, that it is not easy to see how it can stand its ground. It will do so with increasing difficulty, unless the intelligent part of the public can be made to feel its value- to see that it is good there should be differences, even though not for the better, even though, as it may appear to them, some should be for the worse. If the claims of Individuality are ever to be asserted, the time is now, while much is still wanting to complete the enforced assimilation. It is only in the earlier stages that any stand can be successfully made against the encroachment. The demand that all other people shall resemble ourselves grows 
by what it feeds on. If resistance waits till life is reduced nearly to one uniform type, all deviations from that type will come to be considered impious, immoral, even monstrous and contrary to nature. Mankind speedily become unable to conceive diversity, when they have been for some time unaccustomed to see it.

\section{Chapter 4. Of the Limits to the Authority of Society over the Individual.}

What, then, is the rightful limit to the sovereignty of the individual over himself? Where does the authority of society begin? How much of human life should be assigned to individuality, and how much to society?

Each will receive its proper share, if each has that which more particularly concerns it. To individuality should belong the part of life in which it is chiefly the individual that is interested; to society, the part which chiefly interests society.

Though society is not founded on a contract, and though no good purpose is answered by inventing a contract in order to deduce social obligations from it, every one who receives the protection of society owes a return for the benefit, and the fact of living in society renders it indispensable that each should be bound to observe a certain line of conduct towards the rest. This conduct consists, first, in not injuring the interests of one another; or rather certain interests, which, either by express legal provision or by tacit understanding, ought to be considered as rights; and secondly, in each person's bearing his share (to be fixed on some equitable principle) of the labours and sacrifices incurred for defending the society or its members from injury and molestation. These conditions society is justified in enforcing, at all costs to those who endeavour to withhold fulfilment. Nor is this all that society may do. The acts of an individual may be hurtful to others, or wanting in due consideration for their welfare, without going to the length of violating any of their constituted rights. The offender may then be justly punished by opinion, though not by law. As soon as any part of a person's conduct affects prejudicially the interests of others, society has jurisdiction over it, and the question whether the general welfare will or will not be promoted by interfering with it, becomes open to discussion. But there is no room for entertaining any such question when a person's conduct affects the interests of no persons besides himself, or needs not affect 
them unless they like (all the persons concerned being of full age, and the ordinary amount of understanding). In all such cases, there should be perfect freedom, legal and social, to do the action and stand the consequences.

It would be a great misunderstanding of this doctrine to suppose that it is one of selfish indifference, which pretends that human beings have no business with each other's conduct in life, and that they should not concern themselves about the well-doing or well-being of one another, unless their own interest is involved. Instead of any diminution, there is need of a great increase of disinterested exertion to promote the good of others. But disinterested benevolence can find other instruments to persuade people to their good than whips and scourges, either of the literal or the metaphorical sort. I am the last person to undervalue the self-regarding virtues; they are only second in importance, if even second, to the social. It is equally the business of education to cultivate both. But even education works by conviction and persuasion as well as by compulsion, and it is by the former only that, when the period of education is passed, the self-regarding virtues should be inculcated. Human beings owe to each other help to distinguish the better from the worse, and encouragement to choose the former and avoid the latter. They should be for ever stimulating each other to increased exercise of their higher faculties, and increased direction of their feelings and aims towards wise instead of foolish, elevating instead of degrading, objects and contemplations. But neither one person, nor any number of persons, is warranted in saying to another human creature of ripe years, that he shall not do with his life for his own benefit what he chooses to do with it. He is the person most interested in his own well-being: the interest which any other person, except in cases of strong personal attachment, can have in it, is trifling, compared with that which he himself has; the interest which society has in him individually (except as to his conduct to others) is fractional, and altogether indirect; while with respect to his own feelings and circumstances, the most ordinary man or woman has means of knowledge immeasurably surpassing those that can be possessed by any one else. The interference of society to overrule his judgment and purposes in what only regards himself must be grounded on general presumptions; which may be altogether wrong, and even if right, are as likely as not to be misapplied to individual cases, by persons no better acquainted with the circumstances of such cases than those are who look at them merely from without. In this department, therefore, of 
human affairs, Individuality has its proper field of action. In the conduct of human beings towards one another it is necessary that general rules should for the most part be observed, in order that people may know what they have to expect: but in each person's own concerns his individual spontaneity is entitled to free exercise. Considerations to aid his judgment, exhortations to strengthen his will, may be offered to him, even obtruded on him, by others: but he himself is the final judge. All errors which he is likely to commit against advice and warning are far outweighed by the evil of allowing others to constrain him to what they deem his good.

I do not mean that the feelings with which a person is regarded by others ought not to be in any way affected by his self-regarding qualities or deficiencies. This is neither possible nor desirable. If he is eminent in any of the qualities which conduce to his own good, he is, so far, a proper object of admiration. He is so much the nearer to the ideal perfection of human nature. If he is grossly deficient in those qualities, a sentiment the opposite of admiration will follow. There is a degree of folly, and a degree of what may be called (though the phrase is not unobjectionable) lowness or depravation of taste, which, though it cannot justify doing harm to the person who manifests it, renders him necessarily and properly a subject of distaste, or, in extreme cases, even of contempt: a person could not have the opposite qualities in due strength without entertaining these feelings. Though doing no wrong to any one, a person may so act as to compel us to judge him, and feel to him, as a fool, or as a being of an inferior order: and since this judgment and feeling are a fact which he would prefer to avoid, it is doing him a service to warn him of it beforehand, as of any other disagreeable consequence to which he exposes himself. It would be well, indeed, if this good office were much more freely rendered than the common notions of politeness at present permit, and if one person could honestly point out to another that he thinks him in fault, without being considered unmannerly or presuming. We have a right, also, in various ways, to act upon our unfavourable opinion of any one, not to the oppression of his individuality, but in the exercise of ours. We are not bound, for example, to seek his society; we have a right to avoid it (though not to parade the avoidance), for we have a right to choose the society most acceptable to us. We have a right, and it may be our duty, to caution others against him, if we think his example or conversation likely to have a pernicious effect on those with whom he associates. We may give 
others a preference over him in optional good offices, except those which tend to his improvement. In these various modes a person may suffer very severe penalties at the hands of others for faults which directly concern only himself; but he suffers these penalties only in so far as they are the natural and, as it were, the spontaneous consequences of the faults themselves, not because they are purposely inflicted on him for the sake of punishment. A person who shows rashness, obstinacy, selfconceit - who cannot live within moderate means - who cannot restrain himself from hurtful indulgences-who pursues animal pleasures at the expense of those of feeling and intellect-must expect to be lowered in the opinion of others, and to have a less share of their favourable sentiments; but of this he has no right to complain, unless he has merited their favour by special excellence in his social relations, and has thus established a title to their good offices, which is not affected by his demerits towards himself.

What I contend for is, that the inconveniences which are strictly inseparable from the unfavourable judgment of others, are the only ones to which a person should ever be subjected for that portion of his conduct and character which concerns his own good, but which does not affect the interest of others in their relations with him. Acts injurious to others require a totally different treatment. Encroachment on their rights; infliction on them of any loss or damage not justified by his own rights; falsehood or duplicity in dealing with them; unfair or ungenerous use of advantages over them; even selfish abstinence from defending them against injury - these are fit objects of moral reprobation, and, in grave cases, of moral retribution and punishment. And not only these acts, but the dispositions which lead to them, are properly immoral, and fit subjects of disapprobation which may rise to abhorrence. Cruelty of disposition; malice and ill-nature; that most anti-social and odious of all passions, envy; dissimulation and insincerity, irascibility on insufficient cause, and resentment disproportioned to the provocation; the love of domineering over others; the desire to engross more than one's share of advantages (the pleonexia of the Greeks); the pride which derives gratification from the abasement of others; the egotism which thinks self and its concerns more important than everything else, and decides all doubtful questions in its own favour; - - these are moral vices, and constitute a bad and odious moral character: unlike the self-regarding faults previously mentioned, which are not properly immoralities, and to whatever pitch they may be carried, do not constitute wickedness. They may be 
proofs of any amount of folly, or want of personal dignity and selfrespect; but they are only a subject of moral reprobation when they involve a breach of duty to others, for whose sake the individual is bound to have care for himself. What are called duties to ourselves are not socially obligatory, unless circumstances render them at the same time duties to others. The term duty to oneself, when it means anything more than prudence, means self-respect or self-development, and for none of these is any one accountable to his fellow creatures, because for none of them is it for the good of mankind that he be held accountable to them.

The distinction between the loss of consideration which a person may rightly incur by defect of prudence or of personal dignity, and the reprobation which is due to him for an offence against the rights of others, is not a merely nominal distinction. It makes a vast difference both in our feelings and in our conduct towards him whether he displeases us in things in which we think we have a right to control him, or in things in which we know that we have not. If he displeases us, we may express our distaste, and we may stand aloof from a person as well as from a thing that displeases us; but we shall not therefore feel called on to make his life uncomfortable. We shall reflect that he already bears, or will bear, the whole penalty of his error; if he spoils his life by mismanagement, we shall not, for that reason, desire to spoil it still further: instead of wishing to punish him, we shall rather endeavour to alleviate his punishment, by showing him how he may avoid or cure the evils his conduct tends to bring upon him. He may be to us an object of pity, perhaps of dislike, but not of anger or resentment; we shall not treat him like an enemy of society: the worst we shall think ourselves justified in doing is leaving him to himself, if we do not interfere benevolently by showing interest or concern for him. It is far otherwise if he has infringed the rules necessary for the protection of his fellow creatures, individually or collectively. The evil consequences of his acts do not then fall on himself, but on others; and society, as the protector of all its members, must retaliate on him; must inflict pain on him for the express purpose of punishment, and must take care that it be sufficiently severe. In the one case, he is an offender at our bar, and we are called on not only to sit in judgment on him, but, in one shape or another, to execute our own sentence: in the other case, it is not our part to inflict any suffering on him, except what may incidentally follow from our using the same liberty in the regulation of our own affairs, which we allow to 
him in his.

The distinction here pointed out between the part of a person's life which concerns only himself, and that which concerns others, many persons will refuse to admit. How (it may be asked) can any part of the conduct of a member of society be a matter of indifference to the other members? No person is an entirely isolated being; it is impossible for a person to do anything seriously or permanently hurtful to himself, without mischief reaching at least to his near connections, and often far beyond them. If he injures his property, he does harm to those who directly or indirectly derived support from it, and usually diminishes, by a greater or less amount, the general resource; of the community. If he deteriorates his bodily or mental faculties, he not only brings evil upon all who depended on him for any portion of their happiness, but disqualifies himself for rendering the services which he owes to his fellow creatures generally; perhaps becomes a burthen on their affection or benevolence; and if such conduct were very frequent, hardly any offence that is committed would detract more from the general sum of good. Finally, if by his vices or follies a person does no direct harm to others, he is nevertheless (it may be said) injurious by his example; and ought to be compelled to control himself, for the sake of those whom the sight or knowledge of his conduct might corrupt or mislead.

And even (it will be added) if the consequences of misconduct could be confined to the vicious or thoughtless individual, ought society to abandon to their own guidance those who are manifestly unfit for it? If protection against themselves is confessedly due to children and persons under age, is not society equally bound to afford it to persons of mature years who are equally incapable of self-government? If gambling, or drunkenness, or incontinence, or idleness, or uncleanliness, are as injurious to happiness, and as great a hindrance to improvement, as many or most of the acts prohibited by law, why (it may be asked) should not law, so far as is consistent with practicability and social convenience, endeavour to repress these also? And as a supplement to the unavoidable imperfections of law, ought not opinion at least to organise a powerful police against these vices, and visit rigidly with social penalties those who are known to practise them? There is no question here (it may be said) about restricting individuality, or impeding the trial of new and original experiments in living. The only things it is sought to prevent are things which have been tried and condemned from the beginning of the world until now; things which experience has shown not to be useful or 
suitable to any person's individuality. There must be some length of time and amount of experience after which a moral or prudential truth may be regarded as established: and it is merely desired to prevent generation after generation from falling over the same precipice which has been fatal to their predecessors.

I fully admit that the mischief which a person does to himself may seriously affect, both through their sympathies and their interests, those nearly connected with him and, in a minor degree, society at large. When, by conduct of this sort, a person is led to violate a distinct and assignable obligation to any other person or persons, the case is taken out of the self-regarding class, and becomes amenable to moral disapprobation in the proper sense of the term. If, for example, a man, through intemperance or extravagance, becomes unable to pay his debts, or, having undertaken the moral responsibility of a family, becomes from the same cause incapable of supporting or educating them, he is deservedly reprobated, and might be justly punished; but it is for the breach of duty to his family or creditors, not for the extravagance. If the resources which ought to have been devoted to them, had been diverted from them for the most prudent investment, the moral culpability would have been the same. George Barnwell murdered his uncle to get money for his mistress, but if he had done it to set himself up in business, he would equally have been hanged. Again, in the frequent case of a man who causes grief to his family by addiction to bad habits, he deserves reproach for his unkindness or ingratitude; but so he may for cultivating habits not in themselves vicious, if they are painful to those with whom he passes his life, who from personal ties are dependent on him for their comfort. Whoever fails in the consideration generally due to the interests and feelings of others, not being compelled by some more imperative duty, or justified by allowable self-preference, is a subject of moral disapprobation for that failure, but not for the cause of it, nor for the errors, merely personal to himself, which may have remotely led to it. In like manner, when a person disables himself, by conduct purely selfregarding, from the performance of some definite duty incumbent on him to the public, he is guilty of a social offence. No person ought to be punished simply for being drunk; but a soldier or a policeman should be punished for being drunk on duty. Whenever, in short, there is a definite damage, or a definite risk of damage, either to an individual or to the public, the case is taken out of the province of liberty, and placed in that of morality or law. 


\section{6/John Stuart Mill}

But with regard to the merely contingent, or, as it may be called, constructive injury which a person causes to society, by conduct which neither violates any specific duty to the public, nor occasions perceptible hurt to any assignable individual except himself; the inconvenience is one which society can afford to bear, for the sake of the greater good of human freedom. If grown persons are to be punished for not taking proper care of themselves, I would rather it were for their own sake, than under pretence of preventing them from impairing their capacity or rendering to society benefits which society does not pretend it has a right to exact. But I cannot consent to argue the point as if society had no means of bringing its weaker members up to its ordinary standard of rational conduct, except waiting till they do something irrational, and then punishing them, legally or morally, for it. Society has had absolute power over them during all the early portion of their existence: it has had the whole period of childhood and nonage in which to try whether it could make them capable of rational conduct in life. The existing generation is master both of the training and the entire circumstances of the generation to come; it cannot indeed make them perfectly wise and good, because it is itself so lamentably deficient in goodness and wisdom; and its best efforts are not always, in individual cases, its most successful ones; but it is perfectly well able to make the rising generation, as a whole, as good as, and a little better than, itself. If society lets any considerable number of its members grow up mere children, incapable of being acted on by rational consideration of distant motives, society has itself to blame for the consequences. Armed not only with all the powers of education, but with the ascendency which the authority of a received opinion always exercises over the minds who are least fitted to judge for themselves; and aided by the natural penalties which cannot be prevented from falling on those who incur the distaste or the contempt of those who know them; let not society pretend that it needs, besides all this, the power to issue commands and enforce obedience in the personal concerns of individuals, in which, on all principles of justice and policy, the decision ought to rest with those who are to abide the consequences.

Nor is there anything which tends more to discredit and frustrate the better means of influencing conduct than a resort to the worse. If there be among those whom it is attempted to coerce into prudence or temperance any of the material of which vigorous and independent characters are made, they will infallibly rebel against the yoke. No such 
person will ever feel that others have a right to control him in his concerns, such as they have to prevent him from injuring them in theirs; and it easily comes to be considered a mark of spirit and courage to fly in the face of such usurped authority, and do with ostentation the exact opposite of what it enjoins; as in the fashion of grossness which succeeded, in the time of Charles II., to the fanatical moral intolerance of the Puritans. With respect to what is said of the necessity of protecting society from the bad example set to others by the vicious or the self-indulgent; it is true that bad example may have a pernicious effect, especially the example of doing wrong to others with impunity to the wrong-doer. But we are now speaking of conduct which, while it does no wrong to others, is supposed to do great harm to the agent himself: and I do not see how those who believe this can think otherwise than that the example, on the whole, must be more salutary than hurtful, since, if it displays the misconduct, it displays also the painful or degrading consequences which, if the conduct is justly censured, must be supposed to be in all or most cases attendant on it.

But the strongest of all the arguments against the interference of the public with purely personal conduct is that, when it does interfere, the odds are that it interferes wrongly, and in the wrong place. On questions of social morality, of duty to others, the opinion of the public, that is, of an overruling majority, though of wrong, is likely to be still oftener right; because on such questions they are only required to judge of their own interests; of the manner in which some mode of conduct, if allowed to be practised, would effect themselves. But the opinion of a similar majority, imposed as a law on the minority, on questions of self-regarding conduct, is quite as likely to be wrong as right; for in these cases public opinion means, at the best, some people's opinion of what is good or bad for other people; while very of it does not even mean that; the public, with the most perfect indifference, passing over the pleasure or convenience of those whose conduct they censure, and considering only their own preference. There are many who consider as an injury to themselves any conduct which they have a distaste for, and resent it as an outrage to their feelings; as a religious bigot, when charged with disregarding the religious feelings of others, has been known to retort that they disregard his feelings, by persisting in their abominable worship or creed. But there is no parity between the feeling of a person for his own opinion, and the feeling of another who is offended at his holding it; no more than between the desire of a thief to take a purse, and the desire of 
the right owner to keep it. And a person's taste is as much his own peculiar concern as his opinion or his purse. It is easy for any one to imagine an ideal public which leaves the freedom and choice of individuals in all uncertain matters undisturbed, and only requires them to abstain from modes of conduct which universal experience has condemned. But where has there been seen a public which set any such limit to its censorship? or when does the public trouble itself about universal experience? In its interferences with personal conduct it is seldom thinking of anything but the enormity of acting or feeling differently from itself; and this standard of judgment, thinly disguised, is held up to mankind as the dictate of religion and philosophy, by nine-tenths of all moralists and speculative writers. These teach that things are right because they are right; because we feel them to be so. They tell us to search in our own minds and hearts for laws of conduct binding on ourselves and on all others. What can the poor public do but apply these instructions, and make their own personal feelings of good and evil, if they are tolerably unanimous in them, obligatory on all the world?

The evil here pointed out is not one which exists only in theory; and it may perhaps be expected that I should specify the instances in which the public of this age and country improperly invests its own preferences with the character of moral laws. I am not writing an essay on the aberrations of existing moral feeling. That is too weighty a subject to be discussed parenthetically, and by way of illustration. Yet examples are necessary to show that the principle I maintain is of serious and practical moment, and that I am not endeavouring to erect a barrier against imaginary evils. And it is not difficult to show, by abundant instances, that to extend the bounds of what may be called moral police, until it encroaches on the most unquestionably legitimate liberty of the individual, is one of the most universal of all human propensities.

As a first instance, consider the antipathies which men cherish on no better grounds than that persons whose religious opinions are different from theirs do not practise their religious observances, especially their religious abstinences. To cite a rather trivial example, nothing in the creed or practice of Christians does more to envenom the hatred of Mahomedans against them than the fact of their eating pork. There are few acts which Christians and Europeans regard with more unaffected disgust than Mussulmans regard this particular mode of satisfying hunger. It is, in the first place, an offence against their religion; but this circumstance by no means explains either the degree or the kind of their 
repugnance; for wine also is forbidden by their religion, and to partake of it is by all Mussulmans accounted wrong, but not disgusting. Their aversion to the flesh of the "unclean beast" is, on the contrary, of that peculiar character, resembling an instinctive antipathy, which the idea of uncleanness, when once it thoroughly sinks into the feelings, seems always to excite even in those whose personal habits are anything but scrupulously cleanly, and of which the sentiment of religious impurity, so intense in the Hindoos, is a remarkable example. Suppose now that in a people, of whom the majority were Mussulmans, that majority should insist upon not permitting pork to be eaten within the limits of the country. This would be nothing new in Mahomedan countries. ${ }^{9}$ Would it be a legitimate exercise of the moral authority of public opinion? and if not, why not? The practice is really revolting to such a public. They also sincerely think that it is forbidden and abhorred by the Deity. Neither could the prohibition be censured as religious persecution. It might be religious in its origin, but it would not be persecution for religion, since nobody's religion makes it a duty to eat pork. The only tenable ground of condemnation would be that with the personal tastes and self-regarding concerns of individuals the public has no business to interfere.

To come somewhat nearer home: the majority of Spaniards consider it a gross impiety, offensive in the highest degree to the Supreme Being, to worship him in any other manner than the Roman Catholic; and no other public worship is lawful on Spanish soil. The people of all Southern Europe look upon a married clergy as not only irreligious, but unchaste, indecent, gross, disgusting. What do Protestants think of these perfectly sincere feelings, and of the attempt to enforce them against non-Catholics? Yet, if mankind are justified in interfering with each other's liberty in things which do not concern the interests of others, on what principle is it possible consistently to exclude these cases? or who can blame people for desiring to suppress what they regard as a scandal in the sight of God and man? No stronger case can be shown for prohibiting anything which is regarded as a personal immorality, than is made out for suppressing these practices in the eyes of those who regard them as impieties; and unless we are willing to adopt the logic of persecutors, and to say that we may persecute others because we are right, and that they must not persecute us because they are wrong, we must beware of admitting a principle of which we should resent as a gross injustice the application to ourselves.

The preceding instances may be objected to, although unreason- 
ably, as drawn from contingencies impossible among us: opinion, in this country, not being likely to enforce abstinence from meats, or to interfere with people for worshipping, and for either marrying or not marrying, according to their creed or inclination. The next example, however, shall be taken from an interference with liberty which we have by no means passed all danger of. Wherever the Puritans have been sufficiently powerful, as in New England, and in Great Britain at the time of the Commonwealth, they have endeavoured, with considerable success, to put down all public, and nearly all private, amusements: especially music, dancing, public games, or other assemblages for purposes of diversion, and the theatre. There are still in this country large bodies of persons by whose notions of morality and religion these recreations are condemned; and those persons belonging chiefly to the middle class, who are the ascendant power in the present social and political condition of the kingdom, it is by no means impossible that persons of these sentiments may at some time or other command a majority in Parliament. How will the remaining portion of the community like to have the amusements that shall be permitted to them regulated by the religious and moral sentiments of the stricter Calvinists and Methodists? Would they not, with considerable peremptoriness, desire these intrusively pious members of society to mind their own business? This is precisely what should be said to every government and every public, who have the pretension that no person shall enjoy any pleasure which they think wrong. But if the principle of the pretension be admitted, no one can reasonably object to its being acted on in the sense of the majority, or other preponderating power in the country; and all persons must be ready to conform to the idea of a Christian commonwealth, as understood by the early settlers in New England, if a religious profession similar to theirs should ever succeed in regaining its lost ground, as religions supposed to be declining have so often been known to do.

To imagine another contingency, perhaps more likely to be realised than the one last mentioned. There is confessedly a strong tendency in the modern world towards a democratic constitution of society, accompanied or not by popular political institutions. It is affirmed that in the country where this tendency is most completely realised- where both society and the government are most democratic - the United Statesthe feeling of the majority, to whom any appearance of a more showy or costly style of living than they can hope to rival is disagreeable, operates as a tolerably effectual sumptuary law, and that in many parts of 
the Union it is really difficult for a person possessing a very large income to find any mode of spending it which will not incur popular disapprobation. Though such statements as these are doubtless much exaggerated as a representation of existing facts, the state of things they describe is not only a conceivable and possible, but a probable result of democratic feeling, combined with the notion that the public has a right to a veto on the manner in which individuals shall spend their incomes. We have only further to suppose a considerable diffusion of Socialist opinions, and it may become infamous in the eyes of the majority to possess more property than some very small amount, or any income not earned by manual labour. Opinions similar in principle to these already prevail widely among the artisan class, and weigh oppressively on those who are amenable to the opinion chiefly of that class, namely, its own members. It is known that the bad workmen who form the majority of the operatives in many branches of industry, are decidedly of opinion that bad workmen ought to receive the same wages as good, and that no one ought to be allowed, through piecework or otherwise, to earn by superior skill or industry more than others can without it. And they employ a moral police, which occasionally becomes a physical one, to deter skilful workmen from receiving, and employers from giving, a larger remuneration for a more useful service. If the public have any jurisdiction over private concerns, I cannot see that these people are in fault, or that any individual's particular public can be blamed for asserting the same authority over his individual conduct which the general public asserts over people in general.

But, without dwelling upon supposititious cases, there are, in our own day, gross usurpations upon the liberty of private life actually practised, and still greater ones threatened with some expectation of success, and opinions propounded which assert an unlimited right in the public not only to prohibit by law everything which it thinks wrong, but, in order to get at what it thinks wrong, to prohibit a number of things which it admits to be innocent.

Under the name of preventing intemperance, the people of one English colony, and of nearly half the United States, have been interdicted by law from making any use whatever of fermented drinks, except for medical purposes: for prohibition of their sale is in fact, as it is intended to be, prohibition of their use. And though the impracticability of executing the law has caused its repeal in several of the States which had adopted it, including the one from which it derives its name, an attempt 


\section{2/John Stuart Mill}

has notwithstanding been commenced, and is prosecuted with considerable zeal by many of the professed philanthropists, to agitate for a similar law in this country. The association, or "Alliance" as it terms itself, which has been formed for this purpose, has acquired some notoriety through the publicity given to a correspondence between its secretary and one of the very few English public men who hold that a politician's opinions ought to be founded on principles. Lord Stanley's share in this correspondence is calculated to strengthen the hopes already built on him, by those who know how rare such qualities as are manifested in some of his public appearances unhappily are among those who figure in political life. The organ of the Alliance, who would "deeply deplore the recognition of any principle which could be wrested to justify bigotry and persecution," undertakes to point out the "broad and impassable barrier" which divides such principles from those of the association. "All matters relating to thought, opinion, conscience, appear to me," he says, "to be without the sphere of legislation; all pertaining to social act, habit, relation, subject only to a discretionary power vested in the State itself, and not in the individual, to be within it."

No mention is made of a third class, different from either of these, viz., acts and habits which are not social, but individual; although it is to this class, surely, that the act of drinking fermented liquors belongs. Selling fermented liquors, however, is trading, and trading is a social act. But the infringement complained of is not on the liberty of the seller, but on that of the buyer and consumer; since the State might just as well forbid him to drink wine as purposely make it impossible for him to obtain it. The secretary, however, says, "I claim, as a citizen, a right to legislate whenever my social rights are invaded by the social act of another." And now for the definition of these "social rights." "If anything invades my social rights, certainly the traffic in strong drink does. It destroys my primary right of security, by constantly creating and stimulating social disorder. It invades my right of equality, by deriving a profit from the creation of a misery I am taxed to support. It impedes my right to free moral and intellectual development, by surrounding my path with dangers, and by weakening and demoralising society, from which I have a right to claim mutual aid and intercourse." A theory of "social rights" the like of which probably never before found its way into distinct language: being nothing short of this - that it is the absolute social right of every individual, that every other individual shall act in every respect exactly as he ought; that whosoever fails thereof in the smallest particu- 
lar violates my social right, and entitles me to demand from the legislature the removal of the grievance. So monstrous a principle is far more dangerous than any single interference with liberty; there is no violation of liberty which it would not justify; it acknowledges no right to any freedom whatever, except perhaps to that of holding opinions in secret, without ever disclosing them: for, the moment an opinion which I consider noxious passes any one's lips, it invades all the "social rights" attributed to me by the Alliance. The doctrine ascribes to all mankind a vested interest in each other's moral, intellectual, and even physical perfection, to be defined by each claimant according to his own standard.

Another important example of illegitimate interference with the rightful liberty of the individual, not simply threatened, but long since carried into triumphant effect, is Sabbatarian legislation. Without doubt, abstinence on one day in the week, so far as the exigencies of life permit, from the usual daily occupation, though in no respect religiously binding on any except Jews, is a highly beneficial custom. And inasmuch as this custom cannot be observed without a general consent to that effect among the industrious classes, therefore, in so far as some persons by working may impose the same necessity on others, it may be allowable and right that the law should guarantee to each the observance by others of the custom, by suspending the greater operations of industry on a particular day. But this justification, grounded on the direct interest which others have in each individual's observance of the practice, does not apply to the self-chosen occupations in which a person may think fit to employ his leisure; nor does it hold good, in the smallest degree, for legal restrictions on amusements. It is true that the amusement of some is the day's work of others; but the pleasure, not to say the useful recreation, of many, is worth the labour of a few, provided the occupation is freely chosen, and can be freely resigned. The operatives are perfectly right in thinking that if all worked on Sunday, seven days' work would have to be given for six days' wages; but so long as the great mass of employments are suspended, the small number who for the enjoyment of others must still work, obtain a proportional increase of earnings; and they are not obliged to follow those occupations if they prefer leisure to emolument. If a further remedy is sought, it might be found in the establishment by custom of a holiday on some other day of the week for those particular classes of persons. The only ground, therefore, on which restrictions on Sunday amusements can be defended, must be that they are religiously wrong; a motive of legislation which can never be too ear- 


\section{4/John Stuart Mill}

nestly protested against. Deorum injuriae Diis curae. It remains to be proved that society or any of its officers holds a commission from on high to avenge any supposed offence to Omnipotence, which is not also a wrong to our fellow creatures. The notion that it is one man's duty that another should be religious, was the foundation of all the religious persecutions ever perpetrated, and, if admitted, would fully justify them. Though the feeling which breaks out in the repeated attempts to stop railway travelling on Sunday, in the resistance to the opening of Museums, and the like, has not the cruelty of the old persecutors, the state of mind indicated by it is fundamentally the same. It is a determination not to tolerate others in doing what is permitted by their religion, because it is not permitted by the persecutor's religion. It is a belief that God not only abominates the act of the misbeliever, but will not hold us guiltless if we leave him unmolested.

I cannot refrain from adding to these examples of the little account commonly made of human liberty, the language of downright persecution which breaks out from the press of this country whenever it feels called on to notice the remarkable phenomenon of Mormonism. Much might be said on the unexpected and instructive fact that an alleged new revelation, and a religion founded on it, the product of palpable imposture, not even supported by the prestige of extraordinary qualities in its founder, is believed by hundreds of thousands, and has been made the foundation of a society, in the age of newspapers, railways, and the electric telegraph. What here concerns us is, that this religion, like other and better religions, has its martyrs: that its prophet and founder was, for his teaching, put to death by a mob; that others of its adherents lost their lives by the same lawless violence; that they were forcibly expelled, in a body, from the country in which they first grew up; while, now that they have been chased into a solitary recess in the midst of a desert, many in this country openly declare that it would be right (only that it is not convenient) to send an expedition against them, and compel them by force to conform to the opinions of other people. The article of the Mormonite doctrine which is the chief provocative to the antipathy which thus breaks through the ordinary restraints of religious tolerance, is its sanction of polygamy; which, though permitted to Mahomedans, and Hindoos, and Chinese, seems to excite unquenchable animosity when practised by persons who speak English and profess to be a kind of Christians. No one has a deeper disapprobation than I have of this Mormon institution; both for other reasons, and because, far from being in 
any way countenanced by the principle of liberty, it is a direct infraction of that principle, being a mere riveting of the chains of one half of the community, and an emancipation of the other from reciprocity of obligation towards them. Still, it must be remembered that this relation is as much voluntary on the part of the women concerned in it, and who may be deemed the sufferers by it, as is the case with any other form of the marriage institution; and however surprising this fact may appear, it has its explanation in the common ideas and customs of the world, which teaching women to think marriage the one thing needful, make it intelligible that many woman should prefer being one of several wives, to not being a wife at all. Other countries are not asked to recognise such unions, or release any portion of their inhabitants from their own laws on the score of Mormonite opinions. But when the dissentients have conceded to the hostile sentiments of others far more than could justly be demanded; when they have left the countries to which their doctrines were unacceptable, and established themselves in a remote corner of the earth, which they have been the first to render habitable to human beings; it is difficult to see on what principles but those of tyranny they can be prevented from living there under what laws they please, provided they commit no aggression on other nations, and allow perfect freedom of departure to those who are dissatisfied with their ways. A recent writer, in some respects of considerable merit, proposes (to use his own words) not a crusade, but a civilisade, against this polygamous community, to put an end to what seems to him a retrograde step in civilisation. It also appears so to me, but I am not aware that any community has a right to force another to be civilised. So long as the sufferers by the bad law do not invoke assistance from other communities, I cannot admit that persons entirely unconnected with them ought to step in and require that a condition of things with which all who are directly interested appear to be satisfied, should be put an end to because it is a scandal to persons some thousands of miles distant, who have no part or concern in it. Let them send missionaries, if they please, to preach against it; and let them, by any fair means (of which silencing the teachers is not one), oppose the progress of similar doctrines among their own people. If civilisation has got the better of barbarism when barbarism had the world to itself, it is too much to profess to be afraid lest barbarism, after having been fairly got under, should revive and conquer civilisation. A civilisation that can thus succumb to its vanquished enemy, must first have become so degenerate, that neither its appointed priests and teach- 
ers, nor anybody else, has the capacity, or will take the trouble, to stand up for it. If this be so, the sooner such a civilisation receives notice to quit the better. It can only go on from bad to worse, until destroyed and regenerated (like the Western Empire) by energetic barbarians.

\section{Chapter 5. Applications.}

The principles asserted in these pages must be more generally admitted as the basis for discussion of details, before a consistent application of them to all the various departments of government and morals can be attempted with any prospect of advantage. The few observations I propose to make on questions of detail are designed to illustrate the principles, rather than to follow them out to their consequences. I offer, not so much applications, as specimens of application; which may serve to bring into greater clearness the meaning and limits of the two maxims which together form the entire doctrine of this Essay, and to assist the judgment in holding the balance between them, in the cases where it appears doubtful which of them is applicable to the case.

The maxims are, first, that the individual is not accountable to society for his actions, in so far as these concern the interests of no person but himself. Advice, instruction, persuasion, and avoidance by other people if thought necessary by them for their own good, are the only measures by which society can justifiably express its dislike or disapprobation of his conduct. Secondly, that for such actions as are prejudicial to the interests of others, the individual is accountable, and may be subjected either to social or to legal punishment, if society is of opinion that the one or the other is requisite for its protection.

In the first place, it must by no means be supposed, because damage, or probability of damage, to the interests of others, can alone justify the interference of society, that therefore it always does justify such interference. In many cases, an individual, in pursuing a legitimate object, necessarily and therefore legitimately causes pain or loss to others, or intercepts a good which they had a reasonable hope of obtaining. Such oppositions of interest between individuals often arise from bad social institutions, but are unavoidable while those institutions last; and some would be unavoidable under any institutions. Whoever succeeds in an overcrowded profession, or in a competitive examination; whoever is preferred to another in any contest for an object which both desire, reaps benefit from the loss of others, from their wasted exertion 
and their disappointment. But it is, by common admission, better for the general interest of mankind, that persons should pursue their objects undeterred by this sort of consequences. In other words, society admits no right, either legal or moral, in the disappointed competitors to immunity from this kind of suffering; and feels called on to interfere, only when means of success have been employed which it is contrary to the general interest to permit—namely, fraud or treachery, and force.

Again, trade is a social act. Whoever undertakes to sell any description of goods to the public, does what affects the interest of other persons, and of society in general; and thus his conduct, in principle, comes within the jurisdiction of society: accordingly, it was once held to be the duty of governments, in all cases which were considered of importance, to fix prices, and regulate the processes of manufacture. But it is now recognised, though not till after a long struggle, that both the cheapness and the good quality of commodities are most effectually provided for by leaving the producers and sellers perfectly free, under the sole check of equal freedom to the buyers for supplying themselves elsewhere. This is the so-called doctrine of Free Trade, which rests on grounds different from, though equally solid with, the principle of individual liberty asserted in this Essay. Restrictions on trade, or on production for purposes of trade, are indeed restraints; and all restraint, qua restraint, is an evil: but the restraints in question affect only that part of conduct which society is competent to restrain, and are wrong solely because they do not really produce the results which it is desired to produce by them. As the principle of individual liberty is not involved in the doctrine of Free Trade, so neither is it in most of the questions which arise respecting the limits of that doctrine; as, for example, what amount of public control is admissible for the prevention of fraud by adulteration; how far sanitary precautions, or arrangements to protect workpeople employed in dangerous occupations, should be enforced on employers. Such questions involve considerations of liberty, only in so far as leaving people to themselves is always better, caeteris paribus, than controlling them: but that they may be legitimately controlled for these ends is in principle undeniable. On the other hand, there are questions relating to interference with trade which are essentially questions of liberty; such as the Maine Law, already touched upon; the prohibition of the importation of opium into China; the restriction of the sale of poisons; all cases, in short, where the object of the interference is to make it impossible or difficult to obtain a particular commodity. These interferences are ob- 
jectionable, not as infringements on the liberty of the producer or seller, but on that of the buyer.

One of these examples, that of the sale of poisons, opens a new question; the proper limits of what may be called the functions of police; how far liberty may legitimately be invaded for the prevention of crime, or of accident. It is one of the undisputed functions of government to take precautions against crime before it has been committed, as well as to detect and punish it afterwards. The preventive function of government, however, is far more liable to be abused, to the prejudice of liberty, than the punitory function;--for there is hardly any part of the legitimate freedom of action of a human being which would not admit of being represented, and fairly too, as increasing the facilities for some form or other of delinquency. Nevertheless, if a public authority, or even a private person, sees any one evidently preparing to commit a crime, they are not bound to look on inactive until the crime is committed, but may interfere to prevent it. If poisons were never bought or used for any purpose except the commission of murder it would be right to prohibit their manufacture and sale. They may, however, be wanted not only for innocent but for useful purposes, and restrictions cannot be imposed in the one case without operating in the other. Again, it is a proper office of public authority to guard against accidents. If either a public officer or any one else saw a person attempting to cross a bridge which had been ascertained to be unsafe, and there were no time to warn him of his danger, they might seize him and turn him back, without any real infringement of his liberty; for liberty consists in doing what one desires, and he does not desire to fall into the river. Nevertheless, when there is not a certainty, but only a danger of mischief, no one but the person himself can judge of the sufficiency of the motive which may prompt him to incur the risk: in this case, therefore (unless he is a child, or delirious, or in some state of excitement or absorption incompatible with the full use of the reflecting faculty), he ought, I conceive, to be only warned of the danger; not forcibly prevented from exposing himself to it. Similar considerations, applied to such a question as the sale of poisons, may enable us to decide which among the possible modes of regulation are or are not contrary to principle. Such a precaution, for example, as that of labelling the drug with some word expressive of its dangerous character, may be enforced without violation of liberty: the buyer cannot wish not to know that the thing he possesses has poisonous qualities. But to require in all cases the certificate of a medical 
practitioner would make it sometimes impossible, always expensive, to obtain the article for legitimate uses.

The only mode apparent to me, in which difficulties may be thrown in the way of crime committed through this means, without any infringement worth taking into account upon the liberty of those who desire the poisonous substance for other purposes, consists in providing what, in the apt language of Bentham, is called "preappointed evidence." This provision is familiar to every one in the case of contracts. It is usual and right that the law, when a contract is entered into, should require as the condition of its enforcing performance, that certain formalities should be observed, such as signatures, attestation of witnesses, and the like, in order that in case of subsequent dispute there may be evidence to prove that the contract was really entered into, and that there was nothing in the circumstances to render it legally invalid: the effect being to throw great obstacles in the way of fictitious contracts, or contracts made in circumstances which, if known, would destroy their validity. Precautions of a similar nature might be enforced in the sale of articles adapted to be instruments of crime. The seller, for example, might be required to enter in a register the exact time of the transaction, the name and address of the buyer, the precise quality and quantity sold; to ask the purpose for which it was wanted, and record the answer he received. When there was no medical prescription, the presence of some third person might be required, to bring home the fact to the purchaser, in case there should afterwards be reason to believe that the article had been applied to criminal purposes. Such regulations would in general be no material impediment to obtaining the article, but a very considerable one to making an improper use of it without detection.

The right inherent in society, to ward off crimes against itself by antecedent precautions, suggests the obvious limitations to the maxim, that purely self-regarding misconduct cannot properly be meddled with in the way of prevention or punishment. Drunkenness, for example, in ordinary cases, is not a fit subject for legislative interference; but I should deem it perfectly legitimate that a person, who had once been convicted of any act of violence to others under the influence of drink, should be placed under a special legal restriction, personal to himself; that if he were afterwards found drunk, he should be liable to a penalty, and that if when in that state he committed another offence, the punishment to which he would be liable for that other offence should be increased in severity. The making himself drunk, in a person whom drunkenness ex- 
cites to do harm to others, is a crime against others. So, again, idleness, except in a person receiving support from the public, or except when it constitutes a breach of contract, cannot without tyranny be made a subject of legal punishment; but if, either from idleness or from any other avoidable cause, a man fails to perform his legal duties to others, as for instance to support his children, it is no tyranny to force him to fulfil that obligation, by compulsory labour, if no other means are available.

Again, there are many acts which, being directly injurious only to the agents themselves, ought not to be legally interdicted, but which, if done publicly, are a violation of good manners, and coming thus within the category of offences against others, may rightly be prohibited. Of this kind are offences against decency; on which it is unnecessary to dwell, the rather as they are only connected indirectly with our subject, the objection to publicity being equally strong in the case of many actions not in themselves condemnable, nor supposed to be so.

There is another question to which an answer must be found, consistent with the principles which have been laid down. In cases of personal conduct supposed to be blamable, but which respect for liberty precludes society from preventing or punishing, because the evil directly resulting falls wholly on the agent; what the agent is free to do, ought other persons to be equally free to counsel or instigate? This question is not free from difficulty. The case of a person who solicits another to do an act is not strictly a case of self-regarding conduct. To give advice or offer inducements to any one is a social act, and may, therefore, like actions in general which affect others, be supposed amenable to social control. But a little reflection corrects the first impression, by showing that if the case is not strictly within the definition of individual liberty, yet the reasons on which the principle of individual liberty is grounded are applicable to it. If people must be allowed, in whatever concerns only themselves, to act as seems best to themselves, at their own peril, they must equally be free to consult with one another about what is fit to be so done; to exchange opinions, and give and receive suggestions. Whatever it is permitted to do, it must be permitted to advise to do. The question is doubtful only when the instigator derives a personal benefit from his advice; when he makes it his occupation, for subsistence or pecuniary gain, to promote what society and the State consider to be an evil. Then, indeed, a new element of complication is introduced; namely, the existence of classes of persons with an interest opposed to what is considered as the public weal, and whose mode of 
living is grounded on the counteraction of it. Ought this to be interfered with, or not? Fornication, for example, must be tolerated, and so must gambling; but should a person be free to be a pimp, or to keep a gambling-house? The case is one of those which lie on the exact boundary line between two principles, and it is not at once apparent to which of the two it properly belongs.

There are arguments on both sides. On the side of toleration it may be said that the fact of following anything as an occupation, and living or profiting by the practice of it, cannot make that criminal which would otherwise be admissible; that the act should either be consistently permitted or consistently prohibited; that if the principles which we have hitherto defended are true, society has no business, as society, to decide anything to be wrong which concerns only the individual; that it cannot go beyond dissuasion, and that one person should be as free to persuade as another to dissuade. In opposition to this it may be contended, that although the public, or the State, are not warranted in authoritatively deciding, for purposes of repression or punishment, that such or such conduct affecting only the interests of the individual is good or bad, they are fully justified in assuming, if they regard it as bad, that its being so or not is at least a disputable question: That, this being supposed, they cannot be acting wrongly in endeavouring to exclude the influence of solicitations which are not disinterested, of instigators who cannot possibly be impartial—who have a direct personal interest on one side, and that side the one which the State believes to be wrong, and who confessedly promote it for personal objects only. There can surely, it may be urged, be nothing lost, no sacrifice of good, by so ordering matters that persons shall make their election, either wisely or foolishly, on their own prompting, as free as possible from the arts of persons who stimulate their inclinations for interested purposes of their own. Thus (it may be said) though the statutes respecting unlawful games are utterly indefensible - though all persons should be free to gamble in their own or each other's houses, or in any place of meeting established by their own subscriptions, and open only to the members and their visitors-yet public gambling-houses should not be permitted. It is true that the prohibition is never effectual, and that, whatever amount of tyrannical power may be given to the police, gambling-houses can always be maintained under other pretences; but they may be compelled to conduct their operations with a certain degree of secrecy and mystery, so that nobody knows anything about them but those who seek them; and more than this soci- 
ety ought not to aim at.

There is considerable force in these arguments. I will not venture to decide whether they are sufficient to justify the moral anomaly of punishing the accessary, when the principal is (and must be) allowed to go free; of fining or imprisoning the procurer, but not the fornicator-the gambling-house keeper, but not the gambler. Still less ought the common operations of buying and selling to be interfered with on analogous grounds. Almost every article which is bought and sold may be used in excess, and the sellers have a pecuniary interest in encouraging that excess; but no argument can be founded on this, in favour, for instance, of the Maine Law; because the class of dealers in strong drinks, though interested in their abuse, are indispensably required for the sake of their legitimate use. The interest, however, of these dealers in promoting intemperance is a real evil, and justifies the State in imposing restrictions and requiring guarantees which, but for that justification, would be infringements of legitimate liberty.

A further question is, whether the State, while it permits, should nevertheless indirectly discourage conduct which it deems contrary to the best interests of the agent; whether, for example, it should take measures to render the means of drunkenness more costly, or add to the difficulty of procuring them by limiting the number of the places of sale. On this as on most other practical questions, many distinctions require to be made. To tax stimulants for the sole purpose of making them more difficult to be obtained, is a measure differing only in degree from their entire prohibition; and would be justifiable only if that were justifiable. Every increase of cost is a prohibition, to those whose means do not come up to the augmented price; and to those who do, it is a penalty laid on them for gratifying a particular taste. Their choice of pleasures, and their mode of expending their income, after satisfying their legal and moral obligations to the State and to individuals, are their own concern, and must rest with their own judgment. These considerations may seem at first sight to condemn the selection of stimulants as special subjects of taxation for purposes of revenue. But it must be remembered that taxation for fiscal purposes is absolutely inevitable; that in most countries it is necessary that a considerable part of that taxation should be indirect; that the State, therefore, cannot help imposing penalties, which to some persons may be prohibitory, on the use of some articles of consumption. It is hence the duty of the State to consider, in the imposition of taxes, what commodities the consumers can best spare; and a for- 
tiori, to select in preference those of which it deems the use, beyond a very moderate quantity, to be positively injurious. Taxation, therefore, of stimulants, up to the point which produces the largest amount of revenue (supposing that the State needs all the revenue which it yields) is not only admissible, but to be approved of.

The question of making the sale of these commodities a more or less exclusive privilege, must be answered differently, according to the purposes to which the restriction is intended to be subservient. All places of public resort require the restraint of a police, and places of this kind peculiarly, because offences against society are especially apt to originate there. It is, therefore, fit to confine the power of selling these commodities (at least for consumption on the spot) to persons of known or vouched-for respectability of conduct; to make such regulations respecting hours of opening and closing as may be requisite for public surveillance, and to withdraw the licence if breaches of the peace repeatedly take place through the connivance or incapacity of the keeper of the house, or if it becomes a rendezvous for concocting and preparing offences against the law. Any further restriction I do not conceive to be, in principle, justifiable. The limitation in number, for instance, of beer and spirit houses, for the express purpose of rendering them more difficult of access, and diminishing the occasions of temptation, not only exposes all to an inconvenience because there are some by whom the facility would be abused, but is suited only to a state of society in which the labouring classes are avowedly treated as children or savages, and placed under an education of restraint, to fit them for future admission to the privileges of freedom. This is not the principle on which the labouring classes are professedly governed in any free country; and no person who sets due value on freedom will give his adhesion to their being so governed, unless after all efforts have been exhausted to educate them for freedom and govern them as freemen, and it has been definitively proved that they can only be governed as children. The bare statement of the alternative shows the absurdity of supposing that such efforts have been made in any case which needs be considered here. It is only because the institutions of this country are a mass of inconsistencies, that things find admittance into our practice which belong to the system of despotic, or what is called paternal, government, while the general freedom of our institutions precludes the exercise of the amount of control necessary to render the restraint of any real efficacy as a moral education. 
It was pointed out in an early part of this Essay, that the liberty of the individual, in things wherein the individual is alone concerned, implies a corresponding liberty in any number of individuals to regulate by mutual agreement such things as regard them jointly, and regard no persons but themselves. This question presents no difficulty, so long as the will of all the persons implicated remains unaltered; but since that will may change, it is often necessary, even in things in which they alone are concerned, that they should enter into engagements with one another; and when they do, it is fit, as a general rule, that those engagements should be kept. Yet, in the laws, probably, of every country, this general rule has some exceptions. Not only persons are not held to engagements which violate the rights of third parties, but it is sometimes considered a sufficient reason for releasing them from an engagement, that it is injurious to themselves. In this and most other civilised countries, for example, an engagement by which a person should sell himself, or allow himself to be sold, as a slave, would be null and void; neither enforced by law nor by opinion. The ground for thus limiting his power of voluntarily disposing of his own lot in life, is apparent, and is very clearly seen in this extreme case. The reason for not interfering, unless for the sake of others, with a person's voluntary acts, is consideration for his liberty. His voluntary choice is evidence that what he so chooses is desirable, or at least endurable, to him, and his good is on the whole best provided for by allowing him to take his own means of pursuing it. But by selling himself for a slave, be abdicates his liberty; he foregoes any future use of it beyond that single act. He therefore defeats, in his own case, the very purpose which is the justification of allowing him to dispose of himself. He is no longer free; but is thenceforth in a position which has no longer the presumption in its favour, that would be afforded by his voluntarily remaining in it. The principle of freedom cannot require that he should be free not to be free. It is not freedom to be allowed to alienate his freedom. These reasons, the force of which is so conspicuous in this peculiar case, are evidently of far wider application; yet a limit is everywhere set to them by the necessities of life, which continually require, not indeed that we should resign our freedom, but that we should consent to this and the other limitation of it. The principle, however, which demands uncontrolled freedom of action in all that concerns only the agents themselves, requires that those who have become bound to one another, in things which concern no third party, should be able to release one another from the engagement: 
and even without such voluntary release there are perhaps no contracts or engagements, except those that relate to money or money's worth, of which one can venture to say that there ought to be no liberty whatever of retractation.

Baron Wilhelm von Humboldt, in the excellent essay from which I have already quoted, states it as his conviction, that engagements which involve personal relations or services should never be legally binding beyond a limited duration of time; and that the most important of these engagements, marriage, having the peculiarity that its objects are frustrated unless the feelings of both the parties are in harmony with it, should require nothing more than the declared will of either party to dissolve it. This subject is too important, and too complicated, to be discussed in a parenthesis, and I touch on it only so far as is necessary for purposes of illustration. If the conciseness and generality of Baron Humboldt's dissertation had not obliged him in this instance to content himself with enunciating his conclusion without discussing the premises, he would doubtless have recognised that the question cannot be decided on grounds so simple as those to which he confines himself. When a person, either by express promise or by conduct, has encouraged another to rely upon his continuing to act in a certain way-to build expectations and calculations, and stake any part of his plan of life upon that supposition - a new series of moral obligations arises on his part towards that person, which may possibly be overruled, but cannot be ignored. And again, if the relation between two contracting parties has been followed by consequences to others; if it has placed third parties in any peculiar position, or, as in the case of marriage, has even called third parties into existence, obligations arise on the part of both the contracting parties towards those third persons, the fulfilment of which, or at all events the mode of fulfilment, must be greatly affected by the continuance or disruption of the relation between the original parties to the contract. It does not follow, nor can I admit, that these obligations extend to requiring the fulfilment of the contract at all costs to the happiness of the reluctant party; but they are a necessary element in the question; and even if, as Von Humboldt maintains, they ought to make no difference in the legal freedom of the parties to release themselves from the engagement (and I also hold that they ought not to make much difference), they necessarily make a great difference in the moral freedom. A person is bound to take all these circumstances into account before resolving on a step which may affect such important interests of 
others; and if he does not allow proper weight to those interests, he is morally responsible for the wrong. I have made these obvious remarks for the better illustration of the general principle of liberty, and not because they are at all needed on the particular question, which, on the contrary, is usually discussed as if the interest of children was everything, and that of grown persons nothing.

I have already observed that, owing to the absence of any recognised general principles, liberty is often granted where it should be withheld, as well as withheld where it should be granted; and one of the cases in which, in the modern European world, the sentiment of liberty is the strongest, is a case where, in my view, it is altogether misplaced. A person should be free to do as he likes in his own concerns; but he ought not to be free to do as he likes in acting for another, under the pretext that the affairs of the other are his own affairs. The State, while it respects the liberty of each in what specially regards himself, is bound to maintain a vigilant control over his exercise of any power which it allows him to possess over others. This obligation is almost entirely disregarded in the case of the family relations, a case, in its direct influence on human happiness, more important than all others taken together. The almost despotic power of husbands over wives needs not be enlarged upon here, because nothing more is needed for the complete removal of the evil than that wives should have the same rights, and should receive the protection of law in the same manner, as all other persons; and because, on this subject, the defenders of established injustice do not avail themselves of the plea of liberty, but stand forth openly as the champions of power. It is in the case of children that misapplied notions of liberty are a real obstacle to the fulfilment by the State of its duties. One would almost think that a man's children were supposed to be literally, and not metaphorically, a part of himself, so jealous is opinion of the smallest interference of law with his absolute and exclusive control over them; more jealous than of almost any interference with his own freedom of action: so much less do the generality of mankind value liberty than power. Consider, for example, the case of education. Is it not almost a self-evident axiom, that the State should require and compel the education, up to a certain standard, of every human being who is born its citizen? Yet who is there that is not afraid to recognise and assert this truth? Hardly any one indeed will deny that it is one of the most sacred duties of the parents (or, as law and usage now stand, the father), after summoning a human being into the world, to give to that being an edu- 
cation fitting him to perform his part well in life towards others and towards himself. But while this is unanimously declared to be the father's duty, scarcely anybody, in this country, will bear to hear of obliging him to perform it. Instead of his being required to make any exertion or sacrifice for securing education to his child, it is left to his choice to accept it or not when it is provided gratis! It still remains unrecognised, that to bring a child into existence without a fair prospect of being able, not only to provide food for its body, but instruction and training for its mind, is a moral crime, both against the unfortunate offspring and against society; and that if the parent does not fulfil this obligation, the State ought to see it fulfilled, at the charge, as far as possible, of the parent.

Were the duty of enforcing universal education once admitted there would be an end to the difficulties about what the State should teach, and how it should teach, which now convert the subject into a mere battlefield for sects and parties, causing the time and labour which should have been spent in educating to be wasted in quarreling about education. If the government would make up its mind to require for every child a good education, it might save itself the trouble of providing one. It might leave to parents to obtain the education where and how they pleased, and content itself with helping to pay the school fees of the poorer classes of children, and defraying the entire school expenses of those who have no one else to pay for them. The objections which are urged with reason against State education do not apply to the enforcement of education by the State, but to the State's taking upon itself to direct that education; which is a totally different thing. That the whole or any large part of the education of the people should be in State hands, I go as far as any one in deprecating. All that has been said of the importance of individuality of character, and diversity in opinions and modes of conduct, involves, as of the same unspeakable importance, diversity of education. A general State education is a mere contrivance for moulding people to be exactly like one another: and as the mould in which it casts them is that which pleases the predominant power in the government, whether this be a monarch, a priesthood, an aristocracy, or the majority of the existing generation; in proportion as it is efficient and successful, it establishes a despotism over the mind, leading by natural tendency to one over the body. An education established and controlled by the State should only exist, if it exist at all, as one among many competing experiments, carried on for the purpose of example and stimulus, to keep the others up to a certain standard of excellence. 
Unless, indeed, when society in general is in so backward a state that it could not or would not provide for itself any proper institutions of education unless the government undertook the task: then, indeed, the government may, as the less of two great evils, take upon itself the business of schools and universities, as it may that of joint stock companies, when private enterprise, in a shape fitted for undertaking great works of industry, does not exist in the country. But in general, if the country contains a sufficient number of persons qualified to provide education under government auspices, the same persons would be able and willing to give an equally good education on the voluntary principle, under the assurance of remuneration afforded by a law rendering education compulsory, combined with State aid to those unable to defray the expense.

The instrument for enforcing the law could be no other than public examinations, extending to all children, and beginning at an early age. An age might be fixed at which every child must be examined, to ascertain if he (or she) is able to read. If a child proves unable, the father, unless he has some sufficient ground of excuse, might be subjected to a moderate fine, to be worked out, if necessary, by his labour, and the child might be put to school at his expense. Once in every year the examination should be renewed, with a gradually extending range of subjects, so as to make the universal acquisition, and what is more, retention, of a certain minimum of general knowledge virtually compulsory. Beyond that minimum there should be voluntary examinations on all subjects, at which all who come up to a certain standard of proficiency might claim a certificate. To prevent the State from exercising, through these arrangements, an improper influence over opinion, the knowledge required for passing an examination (beyond the merely instrumental parts of knowledge, such as languages and their use) should, even in the higher classes of examinations, be confined to facts and positive science exclusively. The examinations on religion, politics, or other disputed topics, should not turn on the truth or falsehood of opinions, but on the matter of fact that such and such an opinion is held, on such grounds, by such authors, or schools, or churches.

Under this system, the rising generation would be no worse off in regard to all disputed truths than they are at present; they would be brought up either churchmen or dissenters as they now are, the State merely taking care that they should be instructed churchmen, or instructed dissenters. There would be nothing to hinder them from being taught religion, if their parents chose, at the same schools where they were 
taught other things. All attempts by the State to bias the conclusions of its citizens on disputed subjects are evil; but it may very properly offer to ascertain and certify that a person possesses the knowledge requisite to make his conclusions, on any given subject, worth attending to. A student of philosophy would be the better for being able to stand an examination both in Locke and in Kant, whichever of the two he takes up with, or even if with neither: and there is no reasonable objection to examining an atheist in the evidences of Christianity, provided he is not required to profess a belief in them. The examinations, however, in the higher branches of knowledge should, I conceive, be entirely voluntary. It would be giving too dangerous a power to governments were they allowed to exclude any one from professions, even from the profession of teacher, for alleged deficiency of qualifications: and I think, with Wilhelm von Humboldt, that degrees, or other public certificates of scientific or professional acquirements, should be given to all who present themselves for examination, and stand the test; but that such certificates should confer no advantage over competitors other than the weight which may be attached to their testimony by public opinion.

It is not in the matter of education only that misplaced notions of liberty prevent moral obligations on the part of parents from being recognised, and legal obligations from being imposed, where there are the strongest grounds for the former always, and in many cases for the latter also. The fact itself, of causing the existence of a human being, is one of the most responsible actions in the range of human life. To undertake this responsibility - to bestow a life which may be either a curse or a blessing-unless the being on whom it is to be bestowed will have at least the ordinary chances of a desirable existence, is a crime against that being. And in a country either over-peopled, or threatened with being so, to produce children, beyond a very small number, with the effect of reducing the reward of labour by their competition, is a serious offence against all who live by the remuneration of their labour. The laws which, in many countries on the Continent, forbid marriage unless the parties can show that they have the means of supporting a family, do not exceed the legitimate powers of the State: and whether such laws be expedient or not (a question mainly dependent on local circumstances and feelings), they are not objectionable as violations of liberty. Such laws are interferences of the State to prohibit a mischievous act-an act injurious to others, which ought to be a subject of reprobation, and social stigma, even when it is not deemed expedient to superadd legal 
punishment. Yet the current ideas of liberty, which bend so easily to real infringements of the freedom of the individual in things which concern only himself, would repel the attempt to put any restraint upon his inclinations when the consequence of their indulgence is a life or lives of wretchedness and depravity to the offspring, with manifold evils to those sufficiently within reach to be in any way affected by their actions. When we compare the strange respect of mankind for liberty, with their strange want of respect for it, we might imagine that a man had an indispensable right to do harm to others, and no right at all to please himself without giving pain to any one.

I have reserved for the last place a large class of questions respecting the limits of government interference, which, though closely connected with the subject of this Essay, do not, in strictness, belong to it. These are cases in which the reasons against interference do not turn upon the principle of liberty: the question is not about restraining the actions of individuals, but about helping them; it is asked whether the government should do, or cause to be done, something for their benefit, instead of leaving it to be done by themselves, individually or in voluntary combination.

The objections to government interference, when it is not such as to involve infringement of liberty, may be of three kinds.

The first is, when the thing to be done is likely to be better done by individuals than by the government. Speaking generally, there is no one so fit to conduct any business, or to determine how or by whom it shall be conducted, as those who are personally interested in it. This principle condemns the interferences, once so common, of the legislature, or the officers of government, with the ordinary processes of industry. But this part of the subject has been sufficiently enlarged upon by political economists, and is not particularly related to the principles of this Essay.

The second objection is more nearly allied to our subject. In many cases, though individuals may not do the particular thing so well, on the average, as the officers of government, it is nevertheless desirable that it should be done by them, rather than by the government, as a means to their own mental education - a mode of strengthening their active faculties, exercising their judgment, and giving them a familiar knowledge of the subjects with which they are thus left to deal. This is a principal, though not the sole, recommendation of jury trial (in cases not political); of free and popular local and municipal institutions; of the conduct of industrial and philanthropic enterprises by voluntary associations. 
These are not questions of liberty, and are connected with that subject only by remote tendencies; but they are questions of development. It belongs to a different occasion from the present to dwell on these things as parts of national education; as being, in truth, the peculiar training of a citizen, the practical part of the political education of a free people, taking them out of the narrow circle of personal and family selfishness, and accustoming them to the comprehension of joint interests, the management of joint concerns - habituating them to act from public or semipublic motives, and guide their conduct by aims which unite instead of isolating them from one another. Without these habits and powers, a free constitution can neither be worked nor preserved; as is exemplified by the too-often transitory nature of political freedom in countries where it does not rest upon a sufficient basis of local liberties. The management of purely local business by the localities, and of the great enterprises of industry by the union of those who voluntarily supply the pecuniary means, is further recommended by all the advantages which have been set forth in this Essay as belonging to individuality of development, and diversity of modes of action. Government operations tend to be everywhere alike. With individuals and voluntary associations, on the contrary, there are varied experiments, and endless diversity of experience. What the State can usefully do is to make itself a central depository, and active circulator and diffuser, of the experience resulting from many trials. Its business is to enable each experimentalist to benefit by the experiments of others; instead of tolerating no experiments but its own.

The third and most cogent reason for restricting the interference of government is the great evil of adding unnecessarily to its power. Every function superadded to those already exercised by the government causes its influence over hopes and fears to be more widely diffused, and converts, more and more, the active and ambitious part of the public into hangers-on of the government, or of some party which aims at becoming the government. If the roads, the railways, the banks, the insurance offices, the great joint-stock companies, the universities, and the public charities, were all of them branches of the government; if, in addition, the municipal corporations and local boards, with all that now devolves on them, became departments of the central administration; if the employes of all these different enterprises were appointed and paid by the government, and looked to the government for every rise in life; not all the freedom of the press and popular constitution of the legislature would 


\section{2/John Stuart Mill}

make this or any other country free otherwise than in name. And the evil would be greater, the more efficiently and scientifically the administrative machinery was constructed - the more skilful the arrangements for obtaining the best qualified hands and heads with which to work it. In England it has of late been proposed that all the members of the civil service of government should be selected by competitive examination, to obtain for these employments the most intelligent and instructed persons procurable; and much has been said and written for and against this proposal. One of the arguments most insisted on by its opponents is that the occupation of a permanent official servant of the State does not hold out sufficient prospects of emolument and importance to attract the highest talents, which will always be able to find a more inviting career in the professions, or in the service of companies and other public bodies. One would not have been surprised if this argument had been used by the friends of the proposition, as an answer to its principal difficulty. Coming from the opponents it is strange enough. What is urged as an objection is the safety-valve of the proposed system. If indeed all the high talent of the country could be drawn into the service of the government, a proposal tending to bring about that result might well inspire uneasiness. If every part of the business of society which required organised concert, or large and comprehensive views, were in the hands of the government, and if government offices were universally filled by the ablest men, all the enlarged culture and practised intelligence in the country, except the purely speculative, would be concentrated in a numerous bureaucracy, to whom alone the rest of the community would look for all things: the multitude for direction and dictation in all they had to do; the able and aspiring for personal advancement. To be admitted into the ranks of this bureaucracy, and when admitted, to rise therein, would be the sole objects of ambition. Under this regime, not only is the outside public ill-qualified, for want of practical experience, to criticise or check the mode of operation of the bureaucracy, but even if the accidents of despotic or the natural working of popular institutions occasionally raise to the summit a ruler or rulers of reforming inclinations, no reform can be effected which is contrary to the interest of the bureaucracy.

Such is the melancholy condition of the Russian empire, as shown in the accounts of those who have had sufficient opportunity of observation. The Czar himself is powerless against the bureaucratic body; he can send any one of them to Siberia, but he cannot govern without them, 
or against their will. On every decree of his they have a tacit veto, by merely refraining from carrying it into effect. In countries of more advanced civilisation and of a more insurrectionary spirit, the public, accustomed to expect everything to be done for them by the State, or at least to do nothing for themselves without asking from the State not only leave to do it, but even how it is to be done, naturally hold the State responsible for all evil which befalls them, and when the evil exceeds their amount of patience, they rise against the government, and make what is called a revolution; whereupon somebody else, with or without legitimate authority from the nation, vaults into the seat, issues his orders to the bureaucracy, and everything goes on much as it did before; the bureaucracy being unchanged, and nobody else being capable of taking their place.

A very different spectacle is exhibited among a people accustomed to transact their own business. In France, a large part of the people, having been engaged in military service, many of whom have held at least the rank of non commissioned officers, there are in every popular insurrection several persons competent to take the lead, and improvise some tolerable plan of action. What the French are in military affairs, the Americans are in every kind of civil business; let them be left without a government, every body of Americans is able to improvise one, and to carry on that or any other public business with a sufficient amount of intelligence, order, and decision. This is what every free people ought to be: and a people capable of this is certain to be free; it will never let itself be enslaved by any man or body of men because these are able to seize and pull the reins of the central administration. No bureaucracy can hope to make such a people as this do or undergo anything that they do not like. But where everything is done through the bureaucracy, nothing to which the bureaucracy is really adverse can be done at all. The constitution of such countries is an organisation of the experience and practical ability of the nation into a disciplined body for the purpose of governing the rest; and the more perfect that organisation is in itself, the more successful in drawing to itself and educating for itself the persons of greatest capacity from all ranks of the community, the more complete is the bondage of all, the members of the bureaucracy included. For the governors are as much the slaves of their organisation and discipline as the governed are of the governors. A Chinese mandarin is as much the tool and creature of a despotism as the humblest cultivator. An individual Jesuit is to the utmost degree of abasement the slave of his order, 


\section{4/John Stuart Mill}

though the order itself exists for the collective power and importance of its members.

It is not, also, to be forgotten, that the absorption of all the principal ability of the country into the governing body is fatal, sooner or later, to the mental activity and progressiveness of the body itself. Banded together as they are-working a system which, like all systems, necessarily proceeds in a great measure by fixed rules - the official body are under the constant temptation of sinking into indolent routine, or, if they now and then desert that mill-horse round, of rushing into some halfexamined crudity which has struck the fancy of some leading member of the corps; and the sole check to these closely allied, though seemingly opposite, tendencies, the only stimulus which can keep the ability of the body itself up to a high standard, is liability to the watchful criticism of equal ability outside the body. It is indispensable, therefore, that the means should exist, independently of the government, of forming such ability, and furnishing it with the opportunities and experience necessary for a correct judgment of great practical affairs. If we would possess permanently a skilful and efficient body of functionaries-above all, a body able to originate and willing to adopt improvements; if we would not have our bureaucracy degenerate into a pedantocracy, this body must not engross all the occupations which form and cultivate the faculties required for the government of mankind.

To determine the point at which evils, so formidable to human freedom and advancement, begin, or rather at which they begin to predominate over the benefits attending the collective application of the force of society, under its recognised chiefs, for the removal of the obstacles which stand in the way of its well-being; to secure as much of the advantages of centralised power and intelligence as can be had without turning into governmental channels too great a proportion of the general activity - is one of the most difficult and complicated questions in the art of government. It is, in a great measure, a question of detail, in which many and various considerations must be kept in view, and no absolute rule can be laid down. But I believe that the practical principle in which safety resides, the ideal to be kept in view, the standard by which to test all arrangements intended for overcoming the difficulty, may be conveyed in these words: the greatest dissemination of power consistent with efficiency; but the greatest possible centralisation of information, and diffusion of it from the centre. Thus, in municipal administration, there would be, as in the New England States, a very minute 
division among separate officers, chosen by the localities, of all business which is not better left to the persons directly interested; but besides this, there would be, in each department of local affairs, a central superintendence, forming a branch of the general government. The organ of this superintendence would concentrate, as in a focus, the variety of information and experience derived from the conduct of that branch of public business in all the localities, from everything analogous which is done in foreign countries, and from the general principles of political science. This central organ should have a right to know all that is done, and its special duty should be that of making the knowledge acquired in one place available for others. Emancipated from the petty prejudices and narrow views of a locality by its elevated position and comprehensive sphere of observation, its advice would naturally carry much authority; but its actual power, as a permanent institution, should, I conceive, be limited to compelling the local officers to obey the laws laid down for their guidance. In all things not provided for by general rules, those officers should be left to their own judgment, under responsibility to their constituents. For the violation of rules, they should be responsible to law, and the rules themselves should be laid down by the legislature; the central administrative authority only watching over their execution, and if they were not properly carried into effect, appealing, according to the nature of the case, to the tribunals to enforce the law, or to the constituencies to dismiss the functionaries who had not executed it according to its spirit.

Such, in its general conception, is the central superintendence which the Poor Law Board is intended to exercise over the administrators of the Poor Rate throughout the country. Whatever powers the Board exercises beyond this limit were right and necessary in that peculiar case, for the cure of rooted habits of maladministration in matters deeply affecting not the localities merely, but the whole community; since no locality has a moral right to make itself by mismanagement a nest of pauperism, necessarily overflowing into other localities, and impairing the moral and physical condition of the whole labouring community. The powers of administrative coercion and subordinate legislation possessed by the Poor Law Board (but which, owing to the state of opinion on the subject, are very scantily exercised by them), though perfectly justifiable in a case of first-rate national interest, would be wholly out of place in the superintendence of interests purely local. But a central organ of information and instruction for all the localities would be equally 
valuable in all departments of administration. A government cannot have too much of the kind of activity which does not impede, but aids and stimulates, individual exertion and development. The mischief begins when, instead of calling forth the activity and powers of individuals and bodies, it substitutes its own activity for theirs; when, instead of informing, advising, and, upon occasion, denouncing, it makes them work in fetters, or bids them stand aside and does their work instead of them. The worth of a State, in the long run, is the worth of the individuals composing it; and a State which postpones the interests of their mental expansion and elevation to a little more of administrative skill, or of that semblance of it which practice gives, in the details of business; a State which dwarfs its men, in order that they may be more docile instruments in its hands even for beneficial purposes—will find that with small men no great thing can really be accomplished; and that the perfection of machinery to which it has sacrificed everything will in the end avail it nothing, for want of the vital power which, in order that the machine might work more smoothly, it has preferred to banish.

\section{The End}

\section{Notes}

1. These words had scarcely been written, when, as if to give them an emphatic contradiction, occurred the Government Press Prosecutions of 1858. That ill-judged interference with the liberty of public discussion has not, however, induced me to alter a single word in the text, nor has it at all weakened my conviction that, moments of panic excepted, the era of pains and penalties for political discussion has, in our own country, passed away. For, in the first place, the prosecutions were not persisted in; and, in the second, they were never, properly speaking, political prosecutions. The offence charged was not that of criticising institutions, or the acts or persons of rulers, but of circulating what was deemed an immoral doctrine, the lawfulness of Tyrannicide.

If the arguments of the present chapter are of any validity, there ought to exist the fullest liberty of professing and discussing, as a matter of ethical conviction, any doctrine, however immoral it may be considered. It would, therefore, be irrelevant and out of place to examine here, whether the doctrine of Tyrannicide deserves that title. I shall content myself with saying that the subject has been at all 
times one of the open questions of morals; that the act of a private citizen in striking down a criminal, who, by raising himself above the law, has placed himself beyond the reach of legal punishment or control, has been accounted by whole nations, and by some of the best and wisest of men, not a crime, but an act of exalted virtue; and that, right or wrong, it is not of the nature of assassination, but of civil war. As such, I hold that the instigation to it, in a specific case, may be a proper subject of punishment, but only if an overt act has followed, and at least a probable connection can be established between the act and the instigation. Even then, it is not a foreign government, but the very government assailed, which alone, in the exercise of selfdefence, can legitimately punish attacks directed against its own existence.

2. Thomas Pooley, Bodmin Assizes, July 31, 1857. In December following, he received a free pardon from the Crown.

3. George Jacob Holyoake, August 17, 1857; Edward Truelove, July, 1857.

4. Baron de Gleichen, Marlborough Street Police Court, August 4, 1857.

5. Ample warning may be drawn from the large infusion of the passions of a persecutor, which mingled with the general display of the worst parts of our national character on the occasion of the Sepoy insurrection. The ravings of fanatics or charlatans from the pulpit may be unworthy of notice; but the heads of the Evangelical party have announced as their principle for the government of Hindoos and Mahometans, that no schools be supported by public money in which the Bible is not taught, and by necessary consequence that no public employment be given to any but real or pretended Christians. An Under-Secretary of State, in a speech delivered to his constituents on the 12th of November, 1857, is reported to have said: "Toleration of their faith" (the faith of a hundred millions of British subjects), "the superstition which they called religion, by the British Government, had had the effect of retarding the ascendancy of the British name, and preventing the salutary growth of Christianity.... Toleration was the great corner-stone of the religious liberties of this country; but do not let them abuse that precious word toleration. As he understood it, it meant the complete liberty to all, freedom of worship, among Christians, who worshipped upon the same foundation. It meant toleration of all sects and denominations of Christians who believed in the one mediation." I desire to call attention to the fact, that a man who has 


\section{8/John Stuart Mill}

been deemed fit to fill a high office in the government of this country under a liberal ministry, maintains the doctrine that all who do not believe in the divinity of Christ are beyond the pale of toleration. Who, after this imbecile display, can indulge the illusion that religious persecution has passed away, never to return?

6. The Sphere and Duties of Government, from the German of Baron Wilhelm von Humboldt, pp. 11-13.

7. Sterling's Essays.

8. There is something both contemptible and frightful in the sort of evidence on which, of late years, any person can be judicially declared unfit for the management of his affairs; and after his death, his disposal of his property can be set aside, if there is enough of it to pay the expenses of litigation-which are charged on the property itself. All the minute details of his daily life are pried into, and whatever is found which, seen through the medium of the perceiving and describing faculties of the lowest of the low, bears an appearance unlike absolute commonplace, is laid before the jury as evidence of insanity, and often with success; the jurors being little, if at all, less vulgar and ignorant than the witnesses; while the judges, with that extraordinary want of knowledge of human nature and life which continually astonishes us in English lawyers, often help to mislead them. These trials speak volumes as to the state of feeling and opinion among the vulgar with regard to human liberty. So far from setting any value on individuality - so far from respecting the right of each individual to act, in things indifferent, as seems good to his own judgment and inclinations, judges and juries cannot even conceive that a person in a state of sanity can desire such freedom. In former days, when it was proposed to burn atheists, charitable people used to suggest putting them in a madhouse instead: it would be nothing surprising now-a-days were we to see this done, and the doers applauding themselves, because, instead of persecuting for religion, they had adopted so humane and Christian a mode of treating these unfortunates, not without a silent satisfaction at their having thereby obtained their deserts.

9. The case of the Bombay Parsees is a curious instance in point. When this industrious and enterprising tribe, the descendants of the Persian fire-worshippers, flying from their native country before the Caliphs, arrived in Western India, they were admitted to toleration by the Hindoo sovereigns, on condition of not eating beef. When those regions afterwards fell under the dominion of Mahomedan conquerors, the Parsees 
obtained from them a continuance of indulgence, on condition of refraining from pork. What was at first obedience to authority became a second nature, and the Parsees to this day abstain both from beef and pork. Though not required by their religion, the double abstinence has had time to grow into a custom of their tribe; and custom, in the East, is a religion. 